\title{
Computational insights into the mechanism of porphobilinogen synthase
}

Edvin Erdtman, Eric A. C. Bushnell, James W. Gauld and Leif A. Eriksson

The self-archived postprint version of this journal article is available at Linköping University Institutional Repository (DiVA):

http://urn.kb.se/resolve?urn=urn:nbn:se:liu:diva-150069

N.B.: When citing this work, cite the original publication.

Erdtman, E., Bushnell, E. A. C., Gauld, J. W., Eriksson, L. A., (2010), Computational insights into the mechanism of porphobilinogen synthase, Journal of Physical Chemistry B, 114(50), 16860-16870. https://doi.org/10.1021/jp10359od

Original publication available at:

https://doi.org/10.1021/jp103590d

Copyright: American Chemical Society

http://pubs.acs.org/ 


\title{
Computational Insights into the Mechanism of Porphobilinogen Synthase
}

\author{
Edvin Erdtman, ${ }^{\dagger, \perp}$ Eric A. C. Bushnell,,$\stackrel{\ddagger}{ }$ James W. Gauld, $\stackrel{\ddagger}{\ddagger}$ and Leif A. Eriksson*,, \\ School of Science and Technology, Örebro Life Science Center and Modeling and Simulation Research Center, \\ Örebro University, Örebro, Sweden; Department of Chemistry and Biochemistry, University of Windsor, \\ Windsor, Ontario N9B 3P4, Canada; and School of Chemistry, NUI Galway, Galway, Ireland
}

Received: April 21, 2010; Revised Manuscript Received: October 12, 2010

\begin{abstract}
Porphobilinogen synthase (PBGS) is a key enzyme in heme biosynthesis that catalyzes the formation of porphobilinogen (PBG) from two 5-aminolevulinic acid (5-ALA) molecules via formation of intersubstrate $\mathrm{C}-\mathrm{N}$ and $\mathrm{C}-\mathrm{C}$ bonds. The active site consists of several invariant residues, including two lysyl residues (Lys210 and Lys263; yeast numbering) that bind the two substrate moieties as Schiff bases. Based on experimental studies, various reaction mechanisms have been proposed for this enzyme that generally can be classified according to whether the intersubstrate $\mathrm{C}-\mathrm{C}$ or $\mathrm{C}-\mathrm{N}$ bond is formed first. However, the detailed catalytic mechanism of PBGS remains unclear. In the present study, we have employed density functional theory methods in combination with chemical models of the two key lysyl residues and two substrate moieties in order to investigate various proposed reaction steps and gain insight into the mechanism of PBGS. Importantly, it is found that mechanisms in which the intersubstrate $\mathrm{C}-\mathrm{N}$ bond is formed first have a ratelimiting barrier $(17.5 \mathrm{kcal} / \mathrm{mol})$ that is lower than those in which the intersubstrate $\mathrm{C}-\mathrm{C}$ bond is formed first $(22.8 \mathrm{kcal} / \mathrm{mol})$.
\end{abstract}

\section{Introduction}

Porphyrins are biochemically important molecules found in all living organisms. They are commonly found complexed with metal ions such as iron (heme, siroheme), magnesium (chlorophyll), nickel (factor $\mathrm{F}_{430}$ ), and cobalt (vitamin $\mathrm{B}_{12}$ ). The resulting moieties often play key roles as prosthetic groups or coenzymes in, for example, ligand binding and transport, redox catalysis, and photosynthesis. ${ }^{1}$

Within cells, prophyrins are in part synthesized via the common porphyrin pathway. ${ }^{2}$ One enzyme in this process that has recently attracted increasing interest is porphobilinogen synthase (PBGS). This is partly due to the fact that it catalyzes the asymmetric addition and subsequent cyclization of two 5-aminolevulinic acid (5-ALA) substrate molecules to give porphobilinogen (PBG). Furthermore, it is the first common step in porphyrin biosynthesis (Scheme 1 ) ${ }^{3}$ In addition, the incorrect functioning of PBGS via mutation or lead poisoning has been linked to, for instance, inherited porphyria and porphyria-like disorders. $^{4}$

In general, the active site of PBGS has been found to be highly conserved across different species. All residues are hereafter identified according to their yeast numbering (PDB ID $\left.1 \mathrm{H}^{2} \mathrm{O}^{5}\right)$. In particular, the active site contains two lysyl residues: Lys 210 and 263, at the A- and P-site, respectively (Scheme 2). The labeling refers to the acid group (acetyl- or propionyl-) of the PBG product derived from their respective bound 5-ALA moieties (cf. Scheme 1). Experimental mutagenesis studies have suggested that the P-site lysyl is essential for catalysis, while the A-site lysyl is not. The latter is, however,

\footnotetext{
* To whom correspondence should be addressed. E-mail: leif.eriksson@ nuigalway.ie.

† Örebro University.

* University of Windsor.

$\S$ NUI Galway.

${ }^{\perp}$ Currently at the School of Engineering, University College of Borås, Sweden.
}

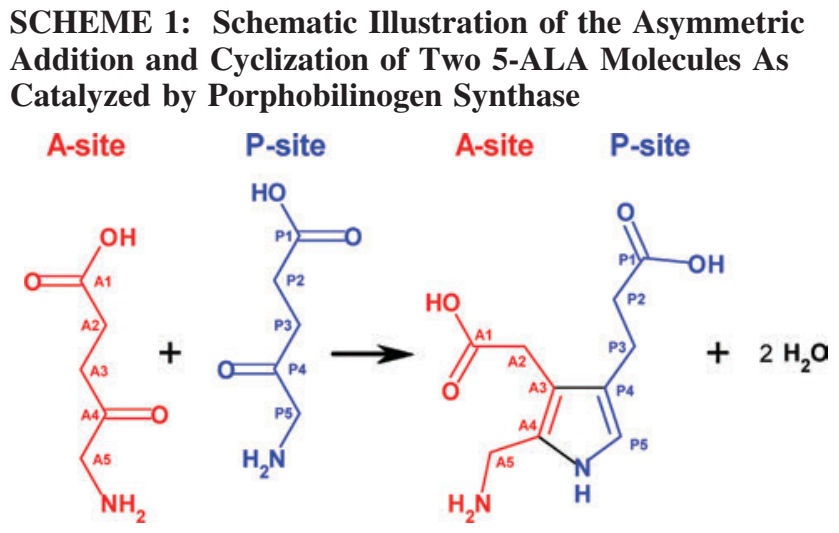

involved in substrate binding at the P-site. ${ }^{6}$ In addition, several polar groups hydrogen bond to the carboxylates of the P(Ser290 and Tyr329) and A-site (Gln236) bound 5-ALA moieties. Other residues (Ser179, Asp131, and Tyr 207) form a polar pocket around, or hydrogen bond to, the terminal amino groups of the 5-ALA substrates. For the P-site 5-ALA, substrate analogues lacking the terminal amino group have been found to be good competitive inhibitors, ${ }^{1}$ thus suggesting that the 5-ALA amino $\cdots$ enzyme interactions are not essential, at least not for binding. A flexible segment of PBGS is also believed to close over the active site when the 5-ALAs are bound. ${ }^{7}$ When closed, two arginyl residues (Arg220 and Arg232) of the "lid" in, for example, human and yeast PBGS (PDB ID $1 \mathrm{H}^{7} \mathrm{O}^{8}$ and $\left.1 \mathrm{OHL}^{9}\right)$, are found to hydrogen bond to the carboxylate of the A-site bound 5-ALA as seen in Scheme 2.

The active site of PBGS has also been found to bind a metal ion (Scheme 2). In some species, this ion is a divalent $\mathrm{Mg}^{2+}$ or monovalent $\mathrm{K}^{+}$or even $\mathrm{Na}^{+},{ }^{10,11}$ whereas within archea, some bacteria, metazoan (including human), and yeast organisms it is found to be a divalent $\mathrm{Zn}^{2+}$ ion. In human and yeast PBGS the $\mathrm{Zn}^{2+}$ coordinates to the thiolates of three cysteines. Since 
SCHEME 2: Schematic Illustration of the Active Site of PBGS with the Two 5-ALA Substrate Moieties Covalently Bound at the A- (Red) and P-site (Blue) via Schiff-Base Linkages ${ }^{a}$

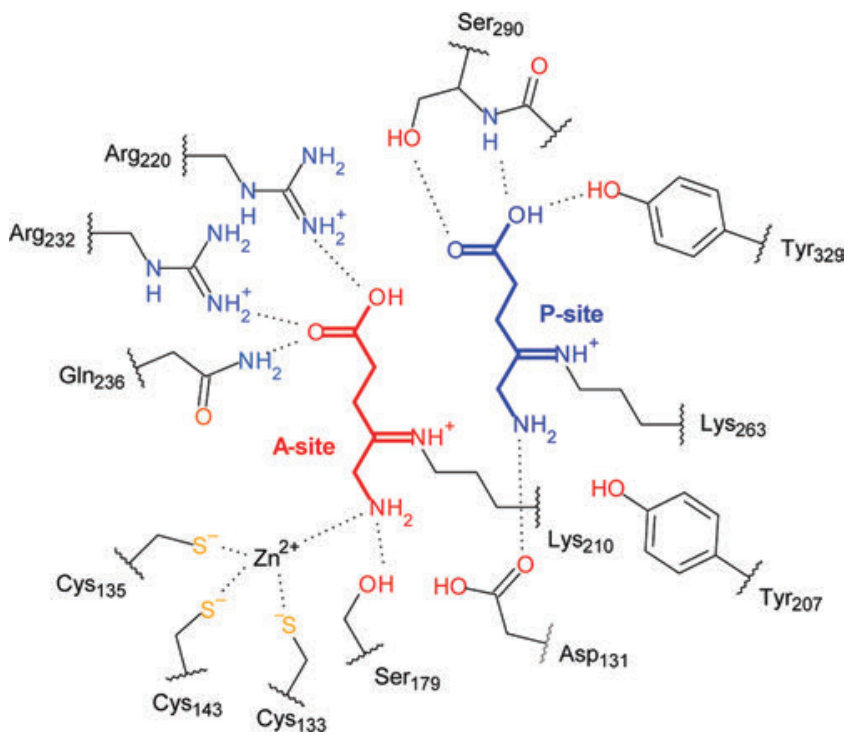

${ }^{a}$ Based on yeast PBGS crystal structures PDB ID $1 \mathrm{H}^{8} \mathrm{O}^{8}$ and $1 \mathrm{OHL} .{ }^{9}$

zinc can simultaneously coordinate four or five ligands, it has been suggested to possibly be involved in the reaction mechanism by binding either $\mathrm{H}_{2} \mathrm{O}^{8}$ or one of the substrates/product. ${ }^{9}$ Indeed, experimental $\mathrm{pH},{ }^{12}$ mutagenesis, ${ }^{13}$ and kinetic ${ }^{14}$ studies have suggested that the $\mathrm{Zn}^{2+}$ plays an important role in substrate binding at the A-site and in stabilizing intermediates and transition structures during the catalytic mechanism..$^{15}$ This has been further supported by experimental $\mathrm{NMR}^{16}$ and X-ray crystallography (PDB ID 1E51 ${ }^{17}$ and $1 \mathrm{OHL}^{9}$ ) studies on various PBGS-bound product complexes. In both cases, the terminal amino groups corresponding to the A-site bound 5-ALA were found to be neutral and coordinated to the $\mathrm{Zn}^{2+}$ ion. It has also been proposed ${ }^{18,19}$ that the A-site 5-ALA carbonyl coordinates to the $\mathrm{Zn}^{2+}$ ion; however, this has not been observed in the crystal structures.

In the late 1960s, Nandi and Shemin ${ }^{20}$ investigated PBGS binding of substrates and inhibitors using $\mathrm{NaBH}_{4}$ to trap the "enzyme-substrate" Schiff base. Based on their results, they concluded that only one such base was formed, specifically at the A-site (Lys210, the lysyl in closest proximity to the $\mathrm{Zn}^{2+}$ ion). More recently, using pulse-labeling studies on bovine and human PBGS, Jordan et al. obtained evidence that an enzyme-substrate Schiff base was instead formed at the P-site lysyl (Lys263). ${ }^{21-24}$ Furthermore, they also suggested that the 5-ALA substrate binds first to the P-site. In contrast, Neier et al. performed PBGS inhibition studies and concluded that two enzyme-substrate Schiff-base linkages are formed, one at each of the A- and P-sites. ${ }^{1}$ Further support for this proposal was provided by crystal structures obtained of PBGS with the inhibitor 4,7-dioxosebacic acid, ${ }^{8,19}$ two 5 -fluorolevulinic acids, ${ }^{10}$ or a putative reaction intermediate ${ }^{25}$ bound within its active site. In addition, it must be noted that it has recently been suggested that the initial trapping studies of Nandi and $\operatorname{Shemin}^{20}$ were unable to "fix" the second enzyme-substrate Schiff base as the active site lid must be closed prior to its formation. ${ }^{18}$

Once both the required 5-ALA substrate moieties are bound within the active site, two intersubstrate covalent bonds are formed to ultimately yield the cyclic product porphobilinogen $(\mathrm{PBG})$ as shown in Scheme 1. One is formed by way of an aldol condensation-type reaction involving $\mathrm{C} 3$ of the A-site bound 5-ALA $\left(\mathrm{C}_{\mathrm{A} 3}\right)$ and $\mathrm{C} 4$ of the P-site bound 5-ALA $\left(\mathrm{C}_{\mathrm{P} 4}\right)$ while the other is formed via a Schiff-base formation reaction between $\mathrm{C}_{\mathrm{A} 5}$ and $\mathrm{N}_{\mathrm{P} 5}$. Unfortunately, despite extensive experimental investigations, the order in which the bonds are formed remains unclear. Consequently, several catalytic mechanisms for PBGS have been proposed and are generally classified as those in which either the $\mathrm{C}_{\mathrm{A} 5}-\mathrm{N}_{\mathrm{P} 5}$ or $\mathrm{C}_{\mathrm{A} 3}-\mathrm{C}_{\mathrm{P} 4}$ is formed first.

" $\mathrm{C}_{\mathrm{A} 5}-\mathrm{N}_{\mathrm{P} 5}$ first" type mechanisms have been proposed by a number of research groups. ${ }^{14,22-24,26}$ Experimental support for such mechanisms has been obtained from inhibition studies in which intermediate analogues containing an appropriate " $\mathrm{C}-\mathrm{N}$ " bond were found to bind tighter to PBGS than those containing an appropriate alternate " $\mathrm{C}-\mathrm{C}$ " bond. ${ }^{14}$ Based on the most recent proposed $\mathrm{C}_{\mathrm{A} 5}-\mathrm{N}_{\mathrm{P} 5}$-first mechanism ${ }^{14}$ and the proposal by Neier ${ }^{1}$ stating that there initially are two enzyme-substrate Schiff bases, we have outlined a possible catalytic path in Scheme 3, identified as Path 1. The mechanism begins with formation of the $\mathrm{C}_{\mathrm{A} 5}-\mathrm{N}_{\mathrm{P} 5}$ intersubstrate bond $(\mathbf{1 A} \rightarrow \mathbf{1 B})$. This is followed by cleavage of the A-site Schiff-base link $(\mathbf{1 B} \rightarrow \mathbf{1 C})$ and transfer of an A-site $\mathrm{H}_{\mathrm{A} 3}$ proton to the $\mathrm{P}$-site Schiff-base nitrogen center $(\mathbf{1 C} \rightarrow \mathbf{1 D})$. The $\mathrm{C}_{\mathrm{A} 3}-\mathrm{C}_{\mathrm{P} 4}$ intersubstrate bond is then formed to give the cyclic intermediate 1E. Cleavage of the P-site enzyme-substrate link is achieved via transfer of the remaining $\mathrm{H}_{\mathrm{A} 3}$ proton to the $\mathrm{P}$-site lysyl nitrogen center $(\mathbf{1 E} \rightarrow \mathbf{1 F} \rightarrow \mathbf{1 G})$. Formation of the desired PBG product (1H) is subsequently obtained through deprotonation of the preporphobilinogen cyclic intermediate $\mathbf{1 G}$ by the P-site lysyl.

Alternate " $\mathrm{C}_{\mathrm{A} 3}-\mathrm{C}_{\mathrm{P} 4}$ first" type mechanisms were first proposed in the 1960s by Nandi and Shemin based on the results of their experimental isotope labeling and inhibitor studies with levulinic acid, and Schiff-base trapping using $\mathrm{NaBH}_{4}{ }^{20}$ More recently, support for this proposed mechanism has been obtained from various experimental studies including inhibition studies, and X-ray crystal structures obtained of a PBGS-bound intermediate, trapped in mutated human PBGS, containing a $\mathrm{C}_{\mathrm{A} 3}-\mathrm{C}_{\mathrm{P} 4}$ bond. ${ }^{1,5,8,12,18,25,27,28}$ Goodwin et al. ${ }^{27}$ furthermore noted that if the $\mathrm{C}_{\mathrm{A} 5}-\mathrm{N}_{\mathrm{P} 5}$ is formed first, formation of the $\mathrm{C}_{\mathrm{A} 3}-\mathrm{C}_{\mathrm{P} 4}$ bond would become an endo-tet cyclization step, which is unfavored according to Baldwin's rules. ${ }^{29}$ As a result, the $\mathrm{C}_{\mathrm{A} 3}-\mathrm{C}_{\mathrm{P} 4}$-first mechanism is presently thought to be the most likely catalytic approach. ${ }^{18,28}$ Consequently, Goodwin et al. proposed the $\mathrm{C}_{\mathrm{A} 3}-\mathrm{C}_{\mathrm{P} 4}$ - -first mechanism shown in Scheme 4, and hereafter specified as Path $2 .{ }^{27}$ This mechanism begins with the transfer of one of the $\mathrm{H}_{\mathrm{A} 3}$ protons to the P-site lysyl nitrogen center, 1A $\rightarrow$ 2B. This is followed by formation of the intersubstrate $\mathrm{C}_{\mathrm{A} 3}-\mathrm{C}_{\mathrm{P} 4}$ bond $(\mathbf{2 B} \rightarrow \mathbf{2 C})$, and immediately thereafter the second intersubstrate bond, the $\mathrm{C}_{\mathrm{A} 4}-\mathrm{N}_{\mathrm{P} 5}$ bond, is formed to give the cyclic intermediate 2D. Electronic rearrangements lead to cleavage of the A-site enzyme-substrate covalent linkage resulting in formation of the double-bond containing cyclic intermediate 1E. From here on the reaction follows the same path as outlined in the $\mathrm{C}_{\mathrm{A} 4}-\mathrm{N}_{\mathrm{P} 5}$-first mechanism (Path 1) given in Scheme 3.

An alternate $\mathrm{C}_{\mathrm{A} 3}-\mathrm{C}_{\mathrm{P} 4}$ - -first mechanism, shown in Scheme 5 and hereafter referred to as Path 3, has also been proposed, in which the P-site substrate-enzyme bond is broken prior to the $\mathrm{C}_{\mathrm{A} 4}-\mathrm{N}_{\mathrm{P} 5}$ bond formation. ${ }^{1,8,12}$ That is, the order in which the enzyme-substrate links are cleaved is in essence reversed compared to that in Path 2. In particular, after formation of the intersubstrate $\mathrm{C}_{\mathrm{A} 3}-\mathrm{C}_{\mathrm{P} 4}$ bond, the second $\mathrm{H}_{\mathrm{A} 3}$ proton is transferred to the P-site lysyl nitrogen center $(\mathbf{2 C} \rightarrow \mathbf{3 D})$. This results in cleavage of the P-site enzyme-substrate bond $(\mathbf{3 D} \rightarrow \mathbf{3 E})$, followed by formation of the $\mathrm{C}_{\mathrm{A} 4}-\mathrm{N}_{\mathrm{P} 5}$ bond, and cleavage of 
SCHEME 3: Path 1 Mechanism of PBGS, with $\mathbf{C}_{\mathrm{A} 4}-\mathbf{N}_{\mathrm{P} 5}$ Intersubstrate Bond Formed First ${ }^{14,24}$

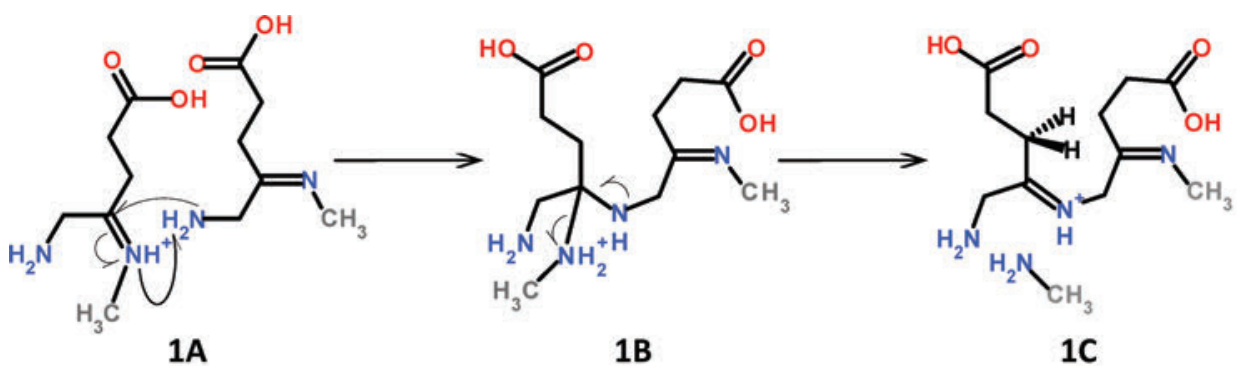

$1 \mathrm{~A}$

1C
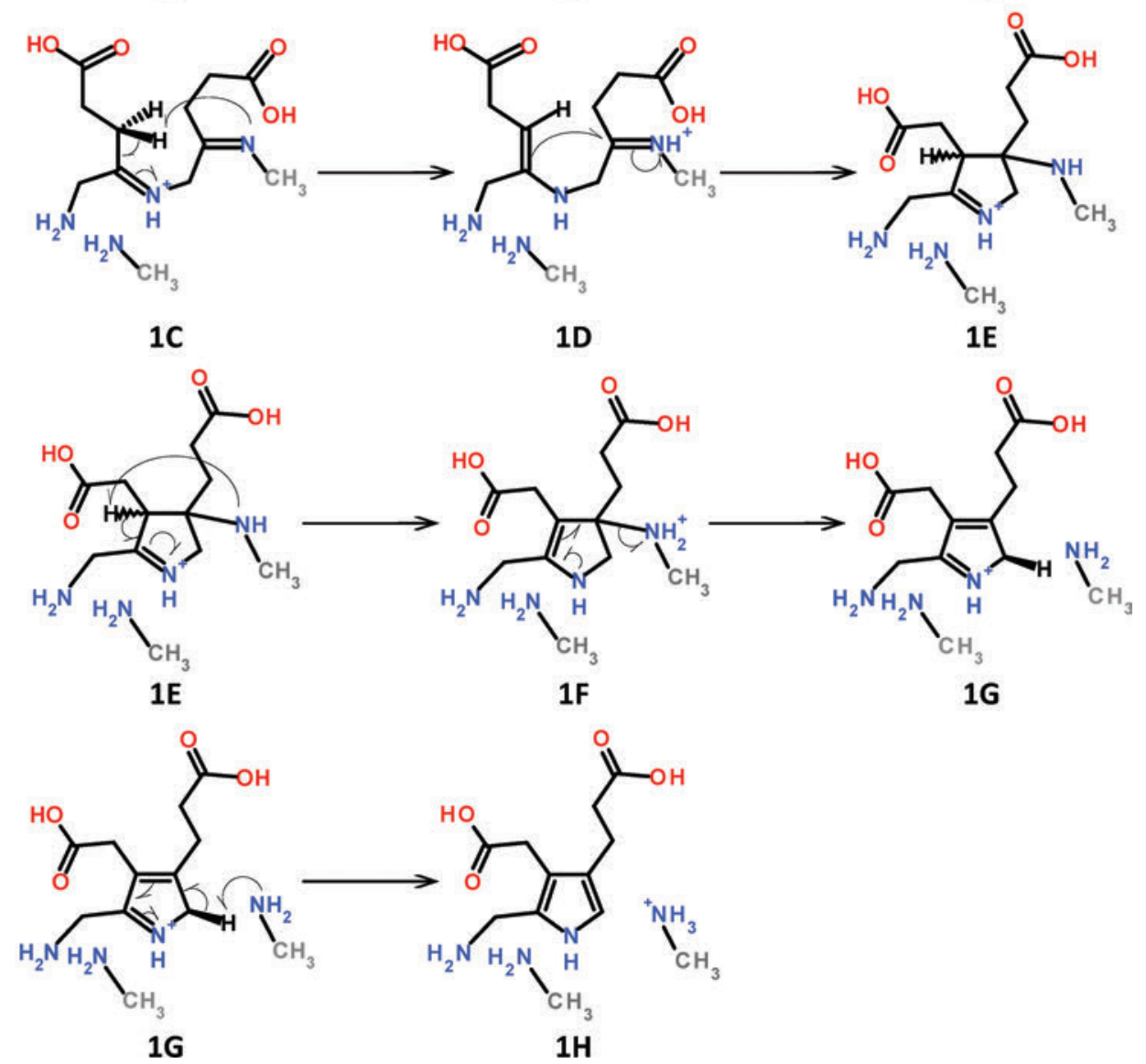

the A-site enzyme-substrate link $(\mathbf{3 E} \rightarrow \mathbf{3 F} \rightarrow \mathbf{1 G}$; Scheme 5). The product PBG $(\mathbf{1 H})$ is again obtained via deprotonation of intermediate $\mathbf{1 G}$ by the P-site amino group.

In addition to the obvious challenges facing a full elucidation of the catalytic mechanism of PBGS, there is the lack of a clear picture of the protonation state of the active site. For instance, the side-chain amino group of lysine has a $\mathrm{p} K_{\mathrm{a}}$ of approximately 10.5 and is thus protonated at physiological $\mathrm{pH}$. Yet in order to form a Schiff base it must be neutral. Based in part on the crystal structures of the hexameric (mutation F12L) and octameric forms of PBGS, it has been suggested that one role of the active site "lid" is to lower the $\mathrm{p} K$ a's of the lysyl residues. ${ }^{25}$ It has been determined that the substrate-derived P-site amine is in fact in its neutral form. ${ }^{16}$ Similarly, it has also been proposed that the amino group of the A-site bound 5-ALA is neutral and ligates to the $\mathrm{Zn}^{2+}$ ion. ${ }^{19}$ Recently, we have shown that Schiffbase formation is favored if the substrate terminal amino group is also neutral. ${ }^{30}$

A key feature of each of the proposed mechanisms above is the three proton transfers. These will be influenced by the protonation states of the active site residues. Unfortunately, it is unclear which, if any, of the active site residues, and in particular the A- and P-site lysyls, that may facilitate these transfers. Results from deuterium isotope experiments indicate that the first deprotonation of the $\mathrm{C}_{\mathrm{A} 3}$ center is the ratedetermining step of the enzyme-catalyzed reaction. ${ }^{31}$ In contrast, Goodwin et al. ${ }^{27}$ have suggested that since the A-site $3 \mathrm{R}$ deuterated $\mathrm{C}_{\mathrm{A} 3}$ gives a greater isotope effect than if the $\mathrm{C}_{\mathrm{A} 3} 3 \mathrm{~S}$ proton is deuterated, the rate-determining step of the mechanism occurs before abstraction of the $\mathrm{C}_{\mathrm{A} 3}$ protons. Furthermore, the first deprotonation step in the reaction involves the $\mathrm{R}$ proton on the A-site $\mathrm{C}_{\mathrm{A} 3}(\mathbf{1 A} \rightarrow \mathbf{2 B}$ in Scheme 4$) .{ }^{27}$ One of the last steps in the reaction is when a proton is removed from $\mathrm{C}_{\mathrm{P} 5}$ of PBGS. The C5 (or $\mathrm{C}_{\mathrm{P} 5}$ ) of 5-ALA was labeled with tritium, and it was found that the pro- $\mathrm{R}$ hydrogen is removed in the enzyme catalysis ${ }^{32,33}(\mathbf{1 G} \rightarrow \mathbf{1 H}$ in Scheme 3$)$.

Clearly, despite extensive and detailed experimental investigations, the exact details of the catalytic mechanism of PBGS remain unclear. A key step toward a full elucidation is an understanding of the component reactions and their inherent chemistry and thermochemistry. To this end, we have in the current study undertaken a computational study employing density functional theory (DFT) methods in combination with chemical models that include the two substrate moieties and 
SCHEME 4: Path 2 Mechanism of PBGS, with $\mathbf{C}_{\mathbf{A} 3}-\mathbf{C}_{\mathbf{P} 4}$ Intersubstrate Bond Formed First ${ }^{9,11,19,27,28 a}$

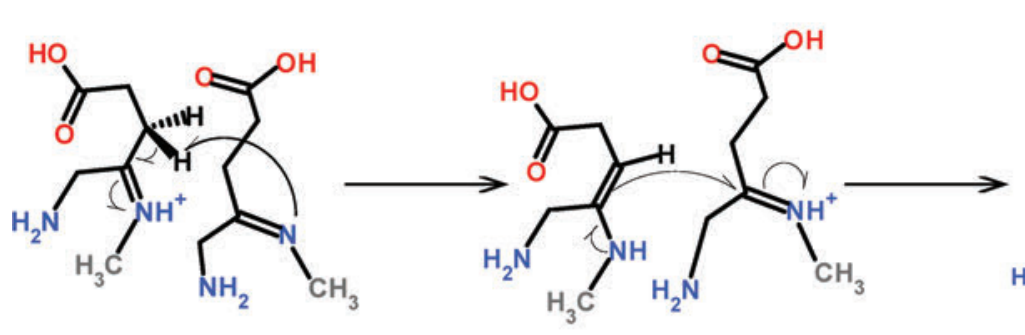

1A

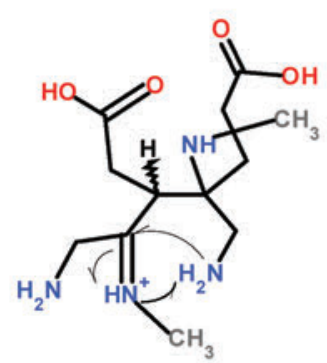

2C
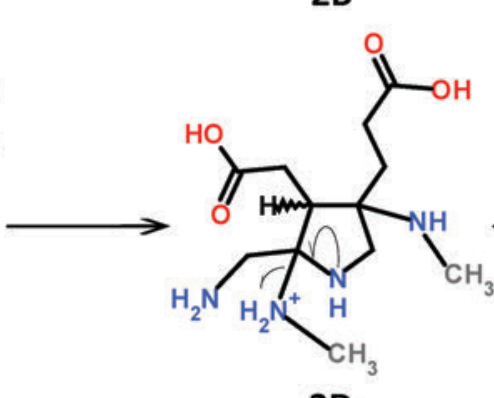

2D
2B

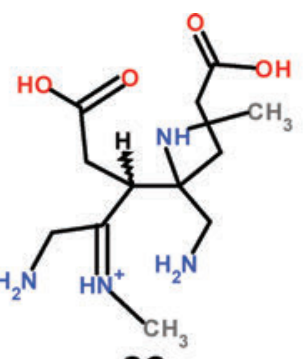

2C

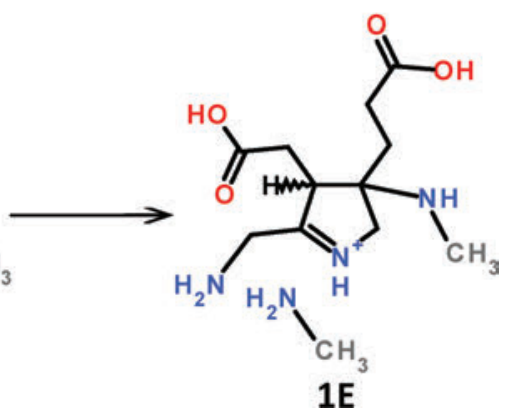

${ }^{a}$ The last steps $(\mathbf{1 E}-\mathbf{1 H})$ follow the same mechanism as Path 1 in Scheme 3.

SCHEME 5: Path 3 Mechanism of PBGS, with $\mathrm{C}_{\mathrm{A} 3}-\mathrm{C}_{\mathrm{P} 4}$ Intersubstrate Bond Formed First, but the P-site Enzyme-Substrate Bond Is Broken Prior to the Cyclization Step ${ }^{1,8,12} a$
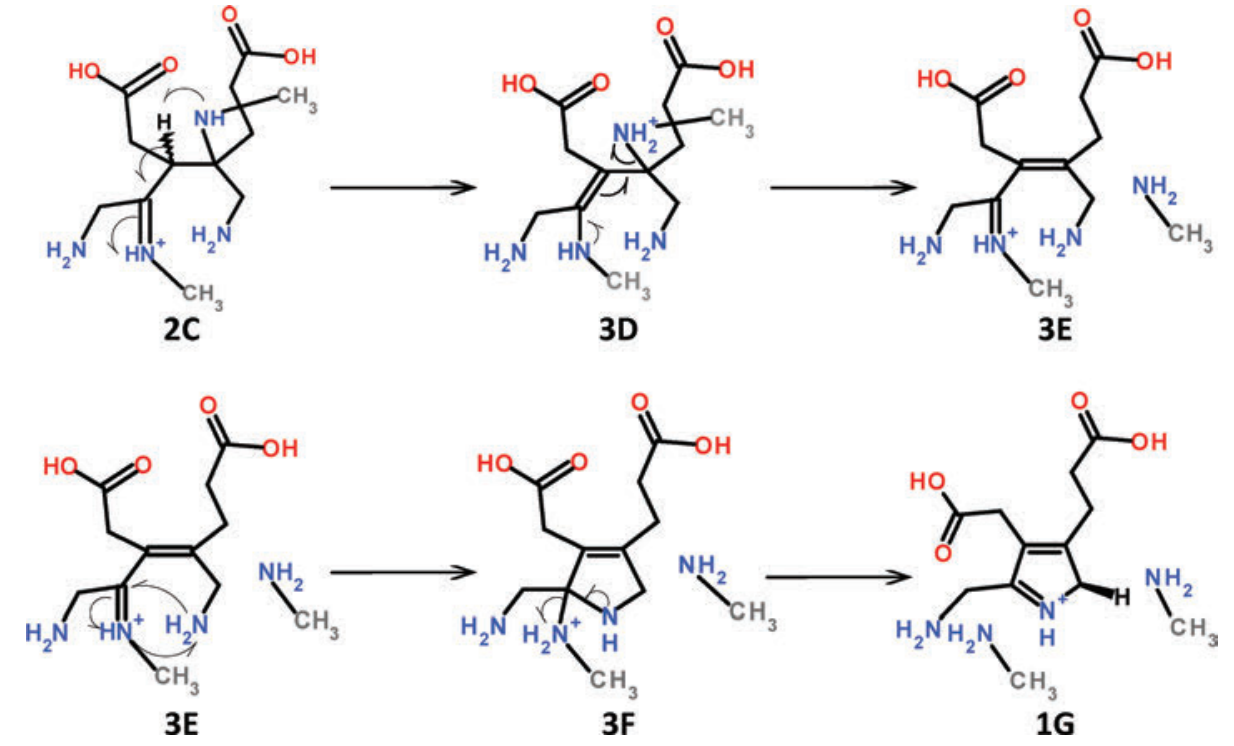

${ }^{a}$ The first steps $(\mathbf{1 A}-\mathbf{2 C})$ follow the same mechanism as Path 2 (Scheme 4) and the last step (1G-1H) the same as Path 1 (Scheme 3).

active site lysyls, in order to investigate the feasibility of the various proposed catalytic mechanisms of PBGS.

\section{Computational Methods}

All calculations were performed using the Gaussian 03 suite of programs. ${ }^{34}$ Optimized geometries and their corresponding harmonic vibrational frequencies were obtained using the hybrid density functional B3LYP, ${ }^{35-39}$ as implemented in Gaussian $03,{ }^{34}$ in combination with the $6-31 \mathrm{G}(\mathrm{d})$ basis set. The nature of all stationary points was confirmed via their vibrational frequencies while IRC's were used to confirm the reaction path between transition structures and their corresponding minima. General solvent effects were modeled by use of the integral equation formalism variant of the polarizable continuum model (IEFPCM) with a dielectric constant ( $\varepsilon$ ) of 78.39, i.e., assuming water as the bulk solvent. Specifically, single-point calculations were performed at the $\operatorname{IEFPCM}(\varepsilon=78.39) / B 3 L Y P / 6-31 G(d)$ level based on the above optimized geometries. The free energy of the systems in aqueous solution was calculated by adding the thermal correction for the Gibbs free energy obtained from the corresponding harmonic frequency calculations, to the energies computed in bulk solvent.

In order to facilitate a comparison of the numerous possible pathways, we have used small chemical model systems that include the two active site lysines, modeled as methylamines (MA, $\mathrm{CH}_{3} \mathrm{NH}_{2}$ ), and the two 5-ALA substrate moieties. In addition, we have considered a singly protonated system in which, in line with previously proposed protonation states of the Schiff bases, ${ }^{16}$ one lysyl is protonated while the other is neutral. It is noted that the carboxyl and amino groups of both 5-ALA's are in their corresponding neutral forms. 


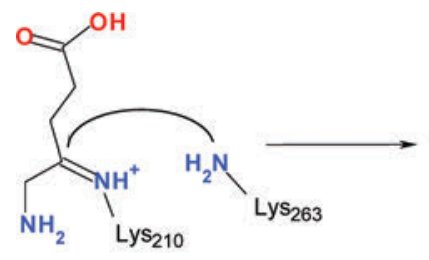

\section{Results and Discussion}

The overall proposed mechanisms of PBGS can be divided into several components. First, the two enzyme-substrate Schiff-base linkages are formed. We have previously examined the possible mechanisms for this step and thus do not consider it further herein. ${ }^{30}$ For completeness, however, it is noted that we considered both neutral and protonated model systems in the study of Schiff-base formation, similar to those used in the present study. It was found that the most feasible reaction mechanism involved Schiff-base formation with a neutral lysyl residue (A-site), assisted by a protonated (P-site) lysyl. In the current study, we assume that the Schiff base has already has been formed between the A-site lysyl amino nitrogen and the carbonyl carbon of a 5-ALA substrate moiety, and initially consider the movement of the Schiff base from the A-site to the P-site lysyl in accordance with that proposed by Goodwin et al., i.e., both lysyls now being neutral. ${ }^{27}$

I. A- to P-site Schiff-Base Transfer. In the mechanism proposed by Goodwin et al. (Scheme 6), ${ }^{27}$ the Schiff base formed at the A-site (Lys210) is first transferred via imine exchange to the P-site lysyl (Lys263). We examined possible mechanisms for this reaction, and their thermodynamic feasibility, using two models in which (i) both the Schiff-base substrate and the P-site lysyl are neutral (TN) and, (ii) the Schiffbase substrate is protonated (previously found to be the product of the most thermodynamically feasible Schiff-base formation mechanism ${ }^{30}$ ) but the P-site lysyl is neutral (TH+). Optimized structures of the reactant complexes, transition structures, and intermediates obtained are given in Figure 1, while the corresponding potential energy surfaces (PESs) are shown in Figure 2.

For the neutral system, the first step is a nucleophilic attack by the nitrogen center of methylamine (our model of the P-site lysyl) at the carbon of the $\mathrm{C}=\mathrm{N}$ substrate-enzyme bond. This occurs concomitantly with a double proton transfer: one from the attacking $-\mathrm{NH}_{2}$ to the carboxylic group, which in turn transfers its proton to the nitrogen of the $\mathrm{C}=\mathrm{N}$ bond (Figure 1). This step proceeds by way of the transition structure $\mathbf{T} \mathbf{S}_{\mathbf{N}}$ at a cost of $13.0 \mathrm{kcal} / \mathrm{mol}$. The product of the reaction, the aminal intermediate $\mathbf{I M}_{\mathbf{N}}$, lies $5.8 \mathrm{kcal} / \mathrm{mol}$ higher in energy than the initial reactant complex $\mathbf{R C}_{\mathbf{N}}$, as shown in Figure $2 \mathrm{a}$. The $\mathrm{C}=\mathrm{N}$ bond lengthens from $1.28 \AA$ in $\mathbf{R C}_{\mathbf{N}}$ to $1.45 \AA$ in $\mathbf{I M}_{\mathbf{N}}$ and is now typical for a single $\mathrm{C}-\mathrm{N}$ bond. The $\mathrm{C}-\mathrm{NH}$ bond formed between the attacking lysyl and 5-ALA is still slightly longer $(1.51 \AA)$ than the other $\mathrm{C}-\mathrm{NH}$ bond, due to the hydrogen bond from the nitrogen atom to the caboxylic acid moiety of 5-ALA
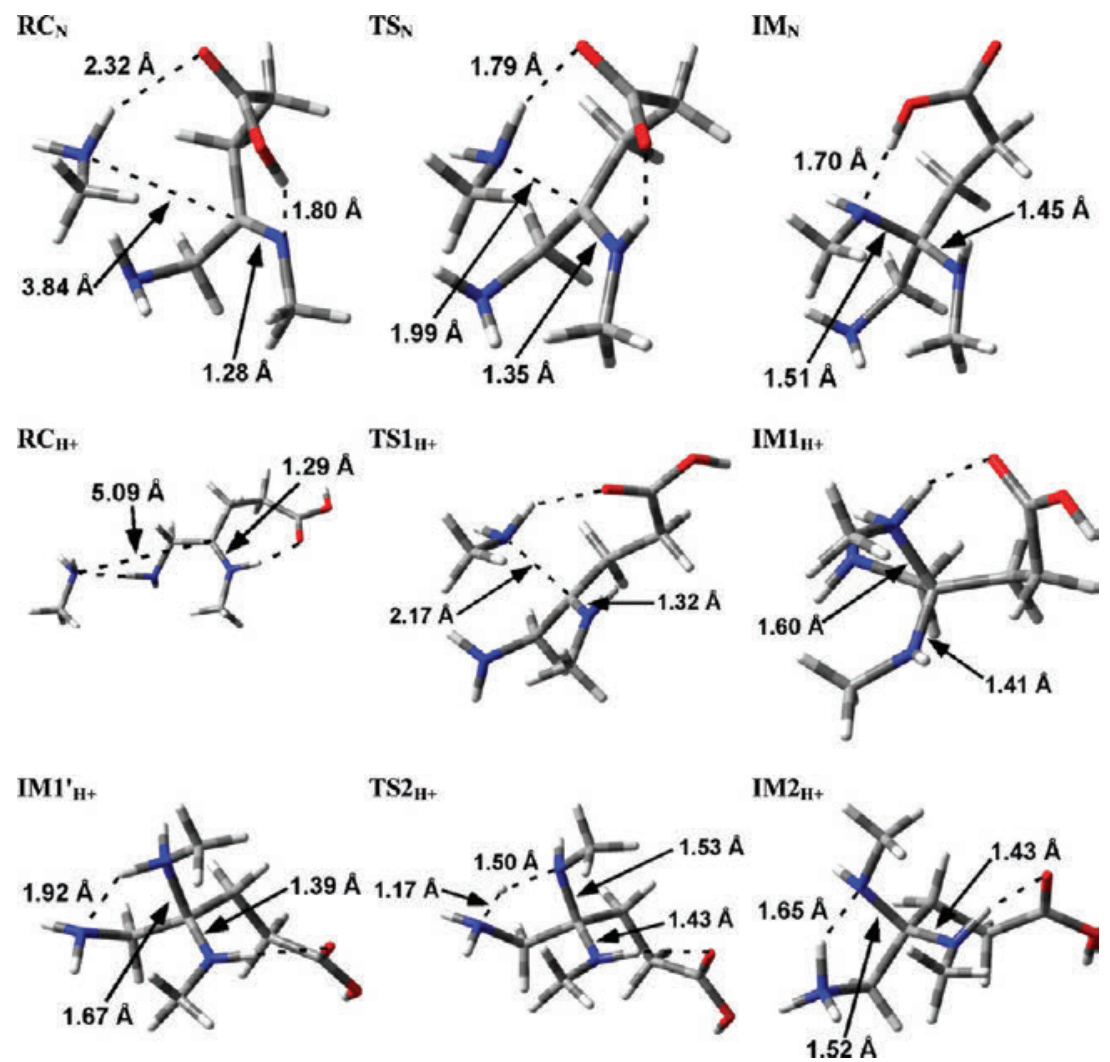

Figure 1. Optimized structures of reactant complexes (RCs), transition structures (TSs), and intermediates (IMs) involved in Schiff-base exchange from the A- to the P-site in which the substrate is neutral $(\mathbf{N})$ or protonated $(\mathbf{H}+)$; see text. 

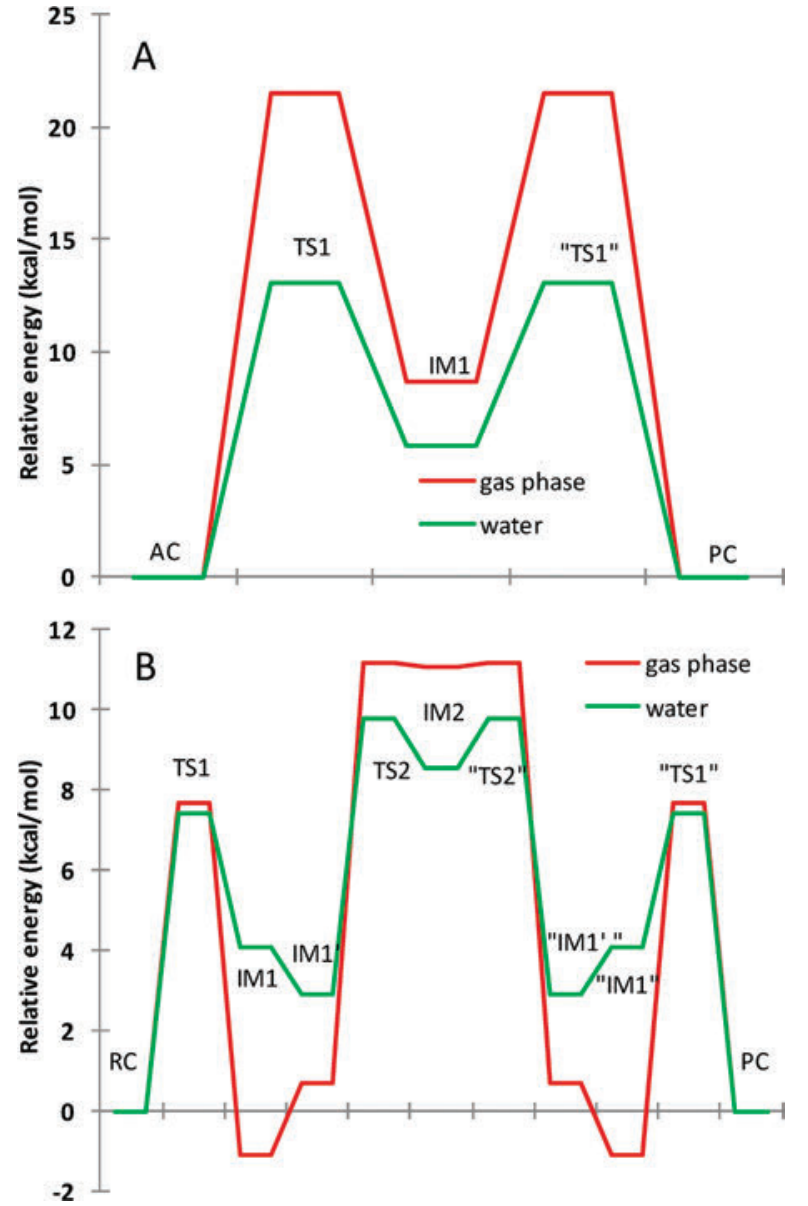

Figure 2. Relative free energy $(\mathrm{kcal} / \mathrm{mol})$ potential energy surfaces for the (A) neutral and (B) protonated system of the Schiff-base transfer in the gas phase (red) and in water (green).
$\left(\mathbf{I M}_{\mathbf{N}}\right.$ Figure 1). This step is followed by a series of, presumably low barrier, rotations such that the carboxylate $-\mathrm{OH}$ group hydrogen bonds to the leaving nitrogen center, giving the alternate aminal complex. Cleavage of the A-site $\mathrm{C}-\mathrm{NH}$ link is achieved through the reverse reaction of the first step; proton transfer from the carboxylate $-\mathrm{OH}$ to the A-site bridging $-\mathrm{NH}-$ nitrogen with simultaneous proton transfer from the $\mathrm{P}$-site $-\mathrm{NH}-$ amine to the carboxylate. The barrier for this step is $7.2 \mathrm{kcal} / \mathrm{mol}$ with respect to $\mathbf{I M}_{\mathbf{N}}$ and is shown in Figure $2 \mathrm{a}$ as a mirror image of the first step.

In the protonated model, we begin with a protonated Schiff-

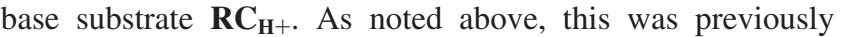
found $^{30}$ to be the product formed via the thermodynamically most feasible pathway for Schiff-base formation within PBGS. It is noted that, at the present level of theory, the alternative complex of protonated methylamine + neutral Schiff-base substrate is just $3.0 \mathrm{kcal} / \mathrm{mol}$ lower in energy in water (not shown). From $\mathbf{R C}_{\mathbf{H}+}$, the $\mathrm{P}$-site neutral amino group can directly attack the carbon center of the Schiff base via $\mathbf{T S 1} \mathbf{1}_{\mathbf{H}+}$ at a cost of $7.4 \mathrm{kcal} / \mathrm{mol}$ to form the protonated aminal intermediate

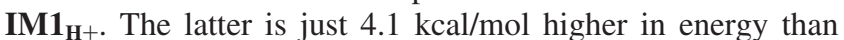
the initial reactant complex $\mathbf{R C}_{\mathbf{H}+}$. It should be noted that in IM1 $1_{\mathbf{H}+}$ one of the amines (that originating from the P-site) is formally protonated, while the other (the A-site) is neutral. A rotation about the $\mathrm{C} 3-\mathrm{C} 4$ bond by $120^{\circ}$ results in a gain of 1.0 $\mathrm{kcal} / \mathrm{mol}$ and generates intermediate $\mathbf{I} \mathbf{M} \mathbf{1}_{\mathbf{H}+}^{\prime}$, with a prolongation of the newly formed $\mathrm{C}-\mathrm{NH}_{2}{ }^{+}$bond to $1.67 \AA$. Cleavage of the A-site link with formation of the P-site Schiff base is achieved in a two-step proton transfer reaction, from the $\mathrm{P}$-site $-\mathrm{NH}_{2}{ }^{+}-$ to the A-site $-\mathrm{NH}-$ group. First, a proton is transferred from the former to the amino group of the original 5-ALA moiety via $\mathbf{T S} 2_{\mathbf{H}+}$ at a cost of $6.9 \mathrm{kcal} / \mathrm{mol}$ to give $\mathbf{I M} \mathbf{2}_{\mathbf{H}+}, 5.7 \mathrm{kcal} /$ mol higher in energy than $\mathbf{R} \mathbf{C}_{\mathbf{H}+}$ (Figure 2). The protonated nitrogen of $\mathbf{I M} 2_{\mathbf{H}}+$ then transfers a proton at a cost of $1.2 \mathrm{kcal} /$ mol to the A-site $-\mathrm{NH}-$, essentially the reverse of the previous

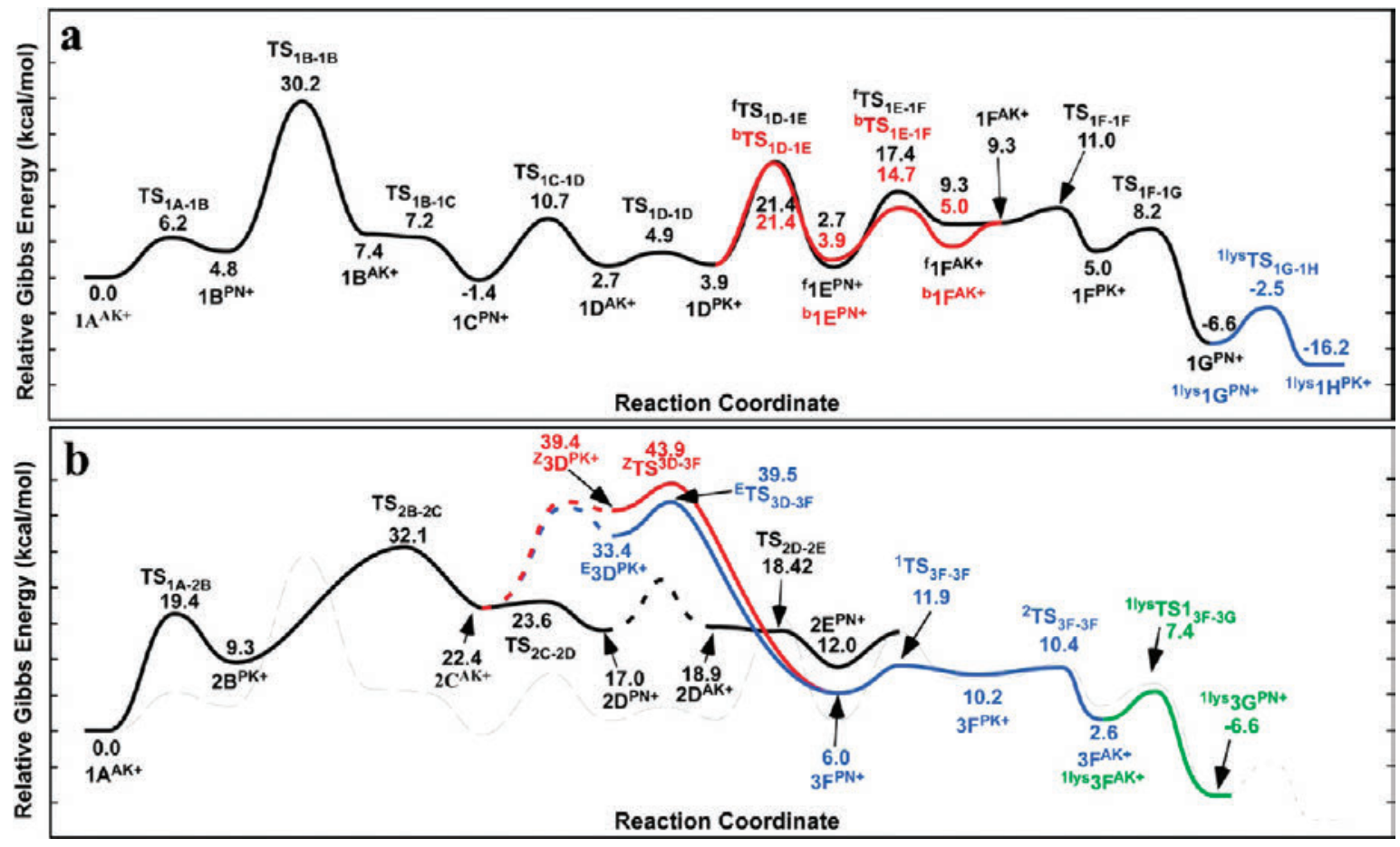

Figure 3. (a) Free energy surface in aqueous solution for Path 1 (black) with the alternate backside steps represented in red. The blue line represents the last step of the reaction in which a methylamine has been removed. (b) Path 2 (black) and Path $3 Z$ (red) and $E$ symmetry (blue) with the thin dotted line of Path 1 for easy comparison of relative energies. The green line represents the last step of the reaction for Path 3 in which a methylamine has been removed. 
reaction step, thus cleaving the $\mathrm{C}-\mathrm{NH}$ enzyme-substrate bond. As for the neutral system the latter is shown in Figure 2B as a mirror image of the nucleophilic attack.

II. Addition and Cyclization of the Two Enzyme-Bound Substrates. Once the Schiff base has been transferred from the A- to the P-site, an enzyme-substrate Schiff base involving a second 5-ALA moiety is formed at the A-site. We have previously considered possible mechanisms for this process and it is hence not discussed further herein. ${ }^{30}$ The next stage in the overall mechanism of PBGS is addition and cyclization of the two Schiff bases to give the desired pyrrolic derivative, porphobilinogen (PBG). This process involves the abstraction or inter/intramolecular transfer of three protons: two from $\mathrm{C}_{\mathrm{A} 3}$ and one from $\mathrm{C}_{\mathrm{P} 5}$. In addition, it also requires the asymmetric formation of bonds between the $\mathrm{A}$ - and $\mathrm{P}$-site $\mathrm{C}_{\mathrm{A} 3}$ and $\mathrm{C}_{\mathrm{P} 4}$, and $\mathrm{C}_{\mathrm{A} 4}$ and $\mathrm{N}_{\mathrm{P} 5}$ centers, respectively. Furthermore, the enzyme must also cleave the two enzyme-substrate imine bonds. As noted in the introduction, the experimentally proposed mechanisms for PBGS differ with respect to the order in which these events occur.

To investigate this stage of the overall mechanism, and to better understand which proposed mechanism may be most feasible, we have primarily considered chemical systems in which one of the Schiff bases is protonated. The potential energy surfaces (PESs) obtained for each of the proposed pathways outlined in the introduction are summarized in Figure 3. It should be noted that due to inherent difficulties commonly encountered with models of this type, namely unrealistic hydrogen bonding between the free methylamines, we have in certain cases (indicated in the text) used a slightly reduced model in which one methylamine is removed.

Path 1: $C_{A 4}-N_{P 5}$ Formation Followed by $C_{A 3}-C_{P 4}$. The overall mechanism as most recently proposed by Jarret et al. ${ }^{14}$ is shown in Scheme 3 and is hereafter referred to as Path 1. Importantly, it should be noted that in Path 1 the formation of the intersubstrate $\mathrm{C}_{\mathrm{A} 4}-\mathrm{N}_{\mathrm{P} 5}$ bond occurs prior to formation of the $\mathrm{C}_{\mathrm{A} 3}-\mathrm{C}_{\mathrm{P} 4}$ bond. The free energy PES obtained in the present study for Path 1 is shown in Figure 3 while the corresponding optimized structures are given in Figure 4.

The initial reactive complex $\mathbf{1} \mathbf{A}^{\mathbf{A K}+}$ for Path 1 is a complex between a protonated Schiff base (the A-site) and a neutral Schiff base (the P-site) in which the P-site amine nitrogen $\left(\mathrm{N}_{\mathrm{P} 5}\right)$ weakly interacts with the A-site $\mathrm{C}_{\mathrm{A} 4}$ center at a distance of 3.09 $\AA$. These Schiff bases are those formed upon covalent attachment of the substrate of PBGS, 5-ALA, to the A- and P-site lysyl residues. It is noted that in $\mathbf{1 A}^{\mathbf{A K}+}$, the mechanistically relevant $\mathrm{N}_{\mathrm{PK}} \cdots \mathrm{H}_{\mathrm{A} 3}$ distance (that is, the distance between the P-site nitrogen center originating from the lysyl residue to the A-site proton $\mathrm{H}_{\mathrm{A} 3}$ ) is coincidentally also $3.09 \AA$ (Figures 4 and 5).

The proposed Path 1 begins with nucleophilic attack of the $\mathrm{P}$-site free amino nitrogen $\left(\mathrm{N}_{\mathrm{P} 5}\right)$ at the $\mathrm{A}$-site $\mathrm{C}_{\mathrm{A} 4}$ carbon center of $\mathbf{1 A}^{\mathrm{AK}+}$ with concomitant transfer of the A-site $\mathrm{H}_{\mathrm{A} 3}$ proton onto the P-site $\mathrm{N}_{\mathrm{PK}}$ center. In the present study, however, this reaction is found to occur stepwise. The first step is the nucleophilic attack of $\mathrm{N}_{\mathrm{P} 5}$ at the $\mathrm{C}_{\mathrm{A} 4}$ center which proceeds via $\mathbf{T S}_{1 \mathrm{~A}-1 \mathbf{B}}$ with a barrier of $6.2 \mathrm{kcal} / \mathrm{mol}$. The resulting intermediate $\mathbf{1} \mathbf{B}^{\mathbf{P N}+}$ lies $4.8 \mathrm{kcal} / \mathrm{mol}$ higher in energy than $\mathbf{1 A}^{\mathbf{A K}+}$. The subsequent step is transfer of the $\mathrm{H}_{\mathrm{A} 3}$ proton onto the $\mathrm{N}_{\mathrm{PK}}$ center resulting in formation of the intermediate $\mathbf{1 B}^{\mathbf{A K}+}$. This step is endergonic by $3.6 \mathrm{kcal} / \mathrm{mol}$. However, with the chemical model used, such a proton transfer necessarily involves a fourmembered ring transition structure (TS), $\mathbf{T S}_{\mathbf{1 B}-\mathbf{1 B}}$. Such strained TS's have previously been shown in related systems to be
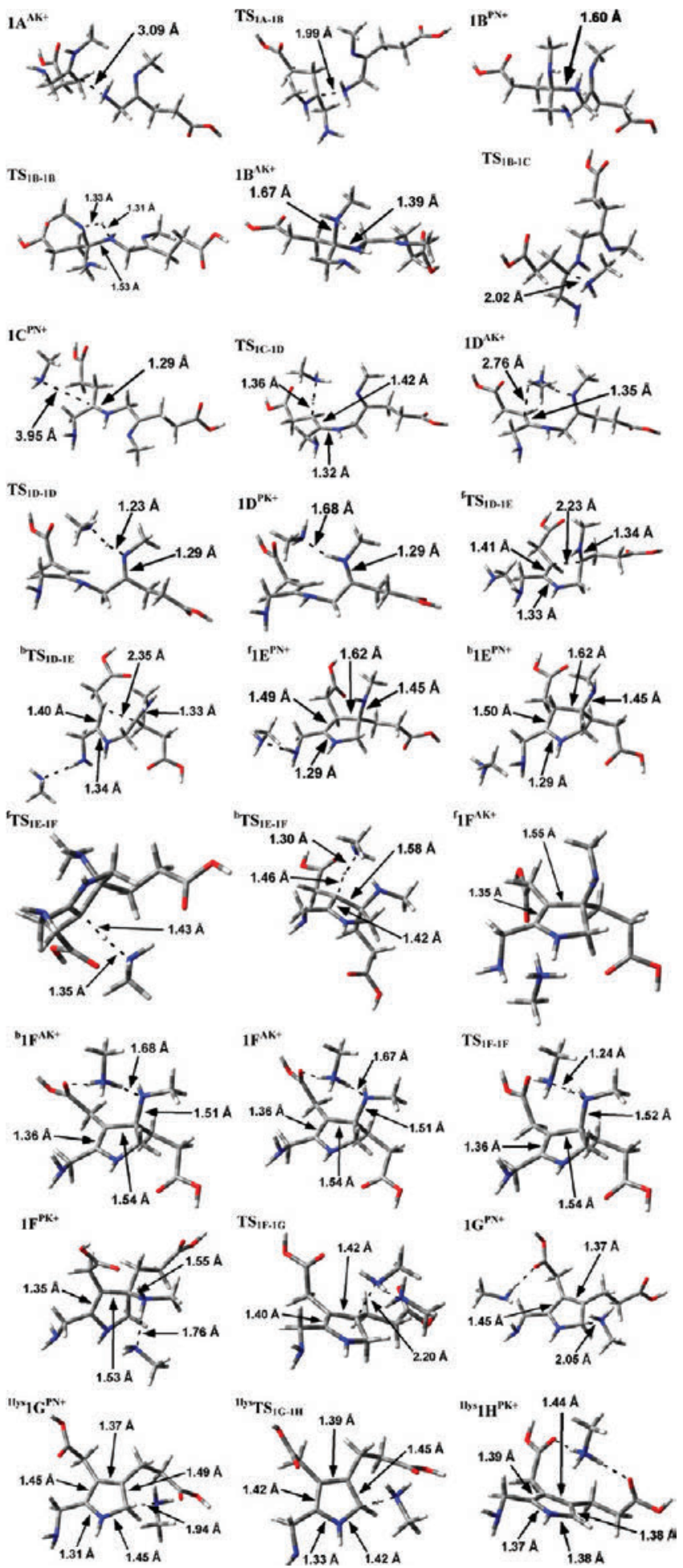

Figure 4. Optimized structures of reactants, intermediates, and transition structures involved in Path 1.

associated with considerable relative energy barriers. ${ }^{30}$ Indeed, in the present study the barrier for this step was calculated to be $25.4 \mathrm{kcal} / \mathrm{mol}$ relative to intermediate $\mathbf{1 B}^{\mathbf{P N}+}$, which is above the commonly accepted thermodynamic upper limit for enzymatic catalysis. ${ }^{40,41}$ However, with such an inherently high barrier it is possible that another active site functional group is involved in this proton transfer. Hence, we also considered possible reactions in which the active-site $\mathrm{H}_{2} \mathrm{O}$ moiety might assist in the proton transfer by including a single water molecule in our model. It was found that the proton-transfer reaction again 

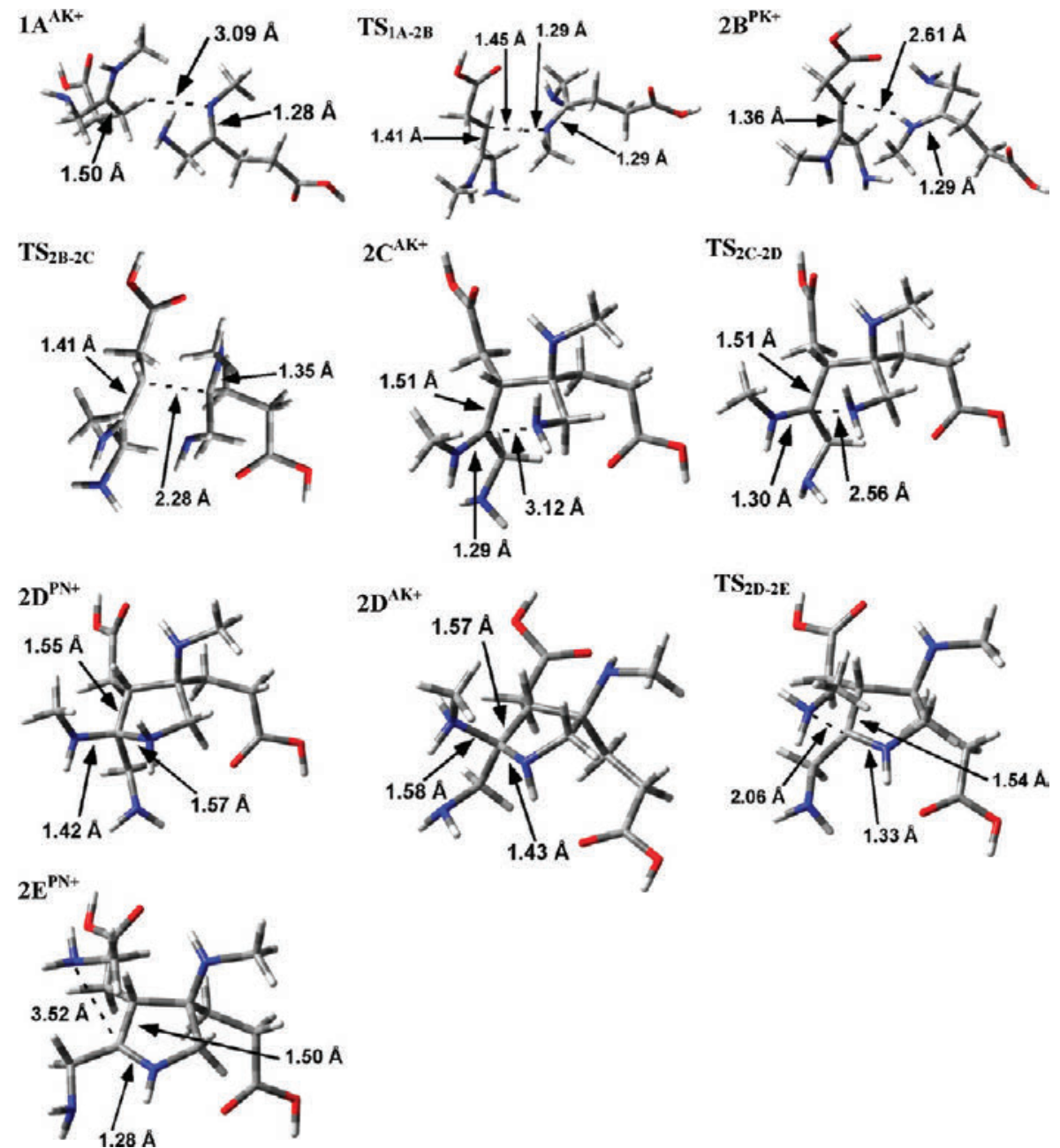

Figure 5. Optimized structures of intermediates and transition structures involved in Path 2.

proceeds in one step, but now via a six-membered TS in which the water abstracts the $\mathrm{H}_{\mathrm{A} 3}$ proton while concomitantly donating one of its own protons onto the $\mathrm{N}_{\mathrm{PK}}$ center. The barrier for the proton transfer was dramatically reduced by over $14 \mathrm{kcal} / \mathrm{mol}$ to just $11.3 \mathrm{kcal} / \mathrm{mol}$ (see Table S1), which is now lower than the upper thermodynamic limit for enzymatic catalysis. ${ }^{40,41}$ It is also noted that the intersubstrate $\mathrm{C}_{\mathrm{A} 4}-\mathrm{N}_{\mathrm{P} 5}$ bond shortens from $1.60 \AA$ in $\mathbf{1 B}^{\mathbf{P N}+}$ to $1.39 \AA$ in $\mathbf{1 B}^{\mathbf{A K}+}$.

In agreement with the proposed mechanism, this can be followed by cleavage of the A-site enzyme-substrate bond via $\mathbf{T S}_{\mathbf{1 B}-\mathbf{1 C}}$ to give intermediate $\mathbf{1 C}^{\mathbf{P N}+}$ lying $8.8 \mathrm{kcal} / \mathrm{mol}$ lower in energy than $\mathbf{1} \mathbf{B}^{\mathbf{A K}+}$. The calculated barrier for this step is in fact found to lie slightly lower in energy (by $0.2 \mathrm{kcal} / \mathrm{mol}$ ) than $\mathbf{1 B}^{\mathrm{AK}+}$. This indicates that this reaction occurs with little or no barrier. Indeed, it is noted that in $\mathbf{1} \mathbf{B}^{\mathbf{A K}+}$ the cleaving $\mathrm{C}-\mathrm{N}$ bond had already lengthened considerably to $1.67 \AA$. In $\mathbf{1 C}^{\mathbf{P N}+}$ the intersubstrate $\mathrm{C}_{\mathrm{A} 4}-\mathrm{N}_{\mathrm{P} 5}$ bond has shortened markedly to 1.29 $\AA$, indicative of a double bond.

The following reaction is proton transfer from $\mathrm{C}_{\mathrm{A} 3}-\mathrm{H}_{\mathrm{A} 3}$ to the P-site lysyl-derived nitrogen center $\left(\mathrm{N}_{\mathrm{PK}}\right)$ (Figure 4$)$. This occurs via a two-step process involving the just released A-site lysyl residue, in which first the $\mathrm{H}_{\mathrm{A} 3}$ proton is transferred to the A-site lysyl amine group via $\mathbf{T S}_{\mathbf{1 C}-\mathbf{1 D}}$, at a cost of $10.9 \mathrm{kcal} /$ mol, to give complex $\mathbf{1 D}^{\mathbf{A K}+}$ lying just $1.6 \mathrm{kcal} / \mathrm{mol}$ higher in energy than $\mathbf{1 C}^{\mathbf{P N}+}$. Subsequently, the now protonated A-site lysyl amino group donates a proton via $\mathbf{T S}_{1 \mathrm{D}-1 \mathrm{D}}$ with a barrier of $4.8 \mathrm{kcal} / \mathrm{mol}$. The resulting complex $\mathbf{1 D}^{\mathbf{P K}+}$ lies $2.8 \mathrm{kcal} /$ mol above $\mathbf{1 C}^{\mathbf{P N}+}$. An alternate reaction mechanism was also found in which the $\mathrm{C}_{\mathrm{A} 3}-\mathrm{H}_{\mathrm{A} 3}$ proton is directly transferred to the P-site lysyl nitrogen. However, this was found to occur with a significantly higher barrier of $20.1 \mathrm{kcal} / \mathrm{mol}$ and was endergonic by $9.4 \mathrm{kcal} / \mathrm{mol}$ (not shown).

The subsequent nucleophilic attack of the A-site $\mathrm{C}_{\mathrm{A} 3}$ center at the $\mathrm{P}$-site $\mathrm{C}_{\mathrm{P} 4}$ can potentially occur from either the "back" or "front" (Figure 4). These reactions occur via ${ }^{\mathbf{b}} \mathbf{T S} \mathbf{S}_{1 \mathrm{D}-\mathbf{1 E}}$ and ${ }^{\mathbf{f}} \mathbf{T S}_{\mathbf{1 D}-\mathbf{1 E}}$, respectively, with comparable reaction barriers of 17.6 and $17.5 \mathrm{kcal} / \mathrm{mol}$ with respect to $\mathbf{1 D}^{\mathbf{P K}+}$. This, naturally, leads to the two similar "conformationally" related product complexes ${ }^{\mathbf{b}} \mathbf{1 E}^{\mathbf{P N}+}$ and ${ }^{\mathbf{f}} \mathbf{1 E} \mathbf{E}^{\mathbf{P N}+}$ lying 0.0 and $1.2 \mathrm{kcal} / \mathrm{mol}$ lower in energy than $\mathbf{1 D}^{\mathbf{P K}+}$. In both ${ }^{\mathbf{b}} \mathbf{1 E}^{\mathbf{P N}+}$ and ${ }^{\mathbf{f}} \mathbf{1 E}^{\mathbf{P N}+}$ the newly formed $\mathrm{C}_{\mathrm{A} 3}-\mathrm{C}_{\mathrm{P} 4}$ bond has a length of $1.62 \AA$ (Figure 4 ).

Overall, the remaining steps are essentially the introduction of a second double bond to give a pyrrole ring and cleavage of the P-site enzyme-substrate bond. At this stage on Path 1, this can occur along either the "back" or "front" paths (see above). In both cases this begins with abstraction of a proton from the $\mathrm{C}_{\mathrm{A} 3}-\mathrm{H}_{\mathrm{A} 3}$ moiety by the free A-site lysyl amino group. This occurs via ${ }^{\mathbf{b}} \mathbf{T S}_{\mathbf{1 \times 1 0 ^ { - 1 }} \mathbf{F}}$ and ${ }^{\mathrm{f}} \mathbf{T S}_{\mathbf{1 \times 1 0 ^ { - 1 }} \mathbf{F}}$, respectively, at costs of 10.8 and $14.7 \mathrm{kcal} / \mathrm{mol}$. The resulting corresponding deprotonated intermediates ${ }^{\mathbf{b}} \mathbf{1} \mathbf{F}^{\mathbf{A K}+}$ and ${ }^{\mathbf{f}} \mathbf{1 F}^{\mathbf{A K}+}$ lie 6.8 and $1.1 \mathrm{kcal} /$ mol higher in energy than their respective "protonated" precursors ${ }^{\mathbf{b}} \mathbf{1} \mathbf{E}^{\mathbf{P N}+}$ and ${ }^{\mathbf{f}} \mathbf{1 E}^{\mathbf{P N}+}$. However, it was found that, in order for the mechanism to proceed further, both ${ }^{\mathbf{b}} \mathbf{1} \mathbf{E}^{\mathbf{P N}+}$ and ${ }^{\mathbf{f}} \mathbf{1} \mathbf{E}^{\mathbf{P N}+}$ must undergo a rearrangement to the common intermediate $\mathbf{1 F}^{\mathrm{AK}+}$ (Figure 3). In this resulting complex the now protonated 
A-site lysyl is hydrogen bonded to the P-site lysyl nitrogen center, i.e., the imine nitrogen (Figure 4).

This is followed by the exergonic proton transfer $(4.4 \mathrm{kcal} /$ mol) from the A-site lysyl to the P-site lysyl nitrogen. This occurs via $\mathbf{T S}_{1 \mathrm{~F}-1 \mathrm{~F}}$ with a markedly low barrier of $1.7 \mathrm{kcal} / \mathrm{mol}$. It is noted that, as a consequence, in the resulting intermediate complex $\mathbf{1 F}^{\mathrm{PK}+}$ (Figure 3) the $\mathrm{N}_{\mathrm{PK}}-\mathrm{C}_{\mathrm{P} 4}$ bond has lengthened to $1.55 \AA$. As previously proposed ${ }^{14}$ for Path 1 (see Scheme 3), this is followed by cleavage of the P-site enzyme-substrate bond. This proceeds via $\mathbf{T S}_{\mathbf{1 F}-\mathbf{1 G}}$ at the decidedly low cost of only $3.3 \mathrm{kcal} / \mathrm{mol}$ to give the penultimate intermediate complex $\mathbf{1 G}^{\mathbf{P N}+}$. Notably, this step is also calculated to be quite exergonic with $\mathbf{1 G}^{\mathbf{P N}+}$ lying $11.6 \mathrm{kcal} / \mathrm{mol}$ lower in energy than $\mathbf{1 F}^{\mathbf{P K}+}$.

For the final step of Path 1, abstraction of the $\mathrm{H}_{\mathrm{P} 5}$ proton by a lysyl residue, it was necessary to reduce our chemical model by removing one of the two free lysyl groups (modeled as $\mathrm{CH}_{3} \mathrm{NH}_{2}$ ) of $1 \mathbf{F}^{\mathbf{P K}+}$. This reduced model is denoted by ${ }^{1 \mathbf{l y s}} \mathbf{1} \mathbf{F}^{\mathbf{P K}+}$ (see Figure 4). This proton abstraction occurs via ${ }^{1 \mathbf{l y s}} \mathbf{T S}_{\mathbf{1 G}-1 \mathbf{H}} \mathbf{w i t h}$ a barrier of $4.1 \mathrm{kcal} / \mathrm{mol}$ to give the final product complex ${ }^{11 y s} 1 \mathbf{H}^{\mathrm{PK}+}$ lying $9.6 \mathrm{kcal} / \mathrm{mol}$ lower in energy than ${ }^{1 / y s} \mathbf{G}_{\mathrm{GH}}^{\mathrm{PN}}$. It is noted that in the final product complex ${ }^{1 \mathrm{ly}} \mathbf{1 H}^{\mathrm{PK}+}$ the aromatic pyrrole ring is now formed, as illustrated by the fact that all bonds within the ring are almost equal in length.

Path 2: $C_{A 3}-C_{P 4}$ Formation Followed by $C_{A 4}-N_{P 5}$. The alternate proposed pathway Path 2 begins from the same initial reactive complex as Path $1, \mathbf{1 A}^{\mathrm{AK}+}$. In contrast to Path 1 , however, it is initiated by a proton transfer from an A-site $\mathrm{C}_{\mathrm{A} 3}-\mathrm{H}$ moiety to the neutral imine nitrogen center of the P-site. This transfer via $\mathbf{T S}_{\mathbf{1 A}-\mathbf{2 B}}$ has a barrier of $19.4 \mathrm{kcal} / \mathrm{mol}$ and forms the intermediate complex $\mathbf{2} \mathbf{B}^{\mathbf{P K}+}$ lying $9.3 \mathrm{kcal} / \mathrm{mol}$ above $1 \mathbf{A}^{\mathrm{AK}+}$ (Figure 3). Notably, it results in formation of a $\mathrm{C}_{\mathrm{A} 3}=\mathrm{C}_{\mathrm{A} 4}$ double bond within $\mathbf{2} \mathbf{B}^{\mathbf{P K}+}$ as indicated by the significantly shortened bond length of $1.36 \AA$ (Figure 5).

Subsequently, the $\mathrm{C}_{\mathrm{A} 3}-\mathrm{C}_{\mathrm{P} 4}$ intersubstrate bond is formed via nucleophilic attack of $\mathrm{C}_{\mathrm{A} 3}$ at the $\mathrm{C}_{\mathrm{P} 4}$ center via $\mathbf{T S}_{\mathbf{2}} \mathbf{B}-\mathbf{2 C}$ at a cost of $22.9 \mathrm{kcal} / \mathrm{mol}$ (see Figure 3). The resulting cross-linked adduct $\mathbf{2 C}^{\mathrm{AK}+}$ lies $13.2 \mathrm{kcal} / \mathrm{mol}$ above $2 \mathbf{B}^{\mathbf{P K}+}$, or $22.4 \mathrm{kcal} /$ mol higher in energy than the initial reactive complex $1 \mathbf{A}^{\mathbf{A K}+}$. As can be seen in Figure 3, the reaction barrier energy of $\mathbf{T S}_{\mathbf{2 B}-2 \mathbf{C}}$ relative to $\mathbf{1 A}^{\mathbf{A K}+}$ is $32.1 \mathrm{kcal} / \mathrm{mol}$. Similar to that noted above, this is markedly higher than that considered to be the thermodynamic upper limit for enzyme catalysis. ${ }^{40,41}$ Structurally, the $\mathrm{C}_{\mathrm{A} 3}-\mathrm{C}_{\mathrm{A} 4}$ bond within $\mathbf{2 C}^{\mathrm{AK}+}$ has lengthened considerably to $1.51 \AA$, indicative of a single bond, while the intersubstrate $\mathrm{C}_{\mathrm{A} 3}-\mathrm{C}_{\mathrm{P} 4}$ bond length is $1.61 \AA$.

This is immediately followed by formation of the second cross-link, the $\mathrm{C}_{\mathrm{A} 4}-\mathrm{N}_{\mathrm{P} 5}$ bond. Analogous to formation of the first intersubstrate bond, this involves nucleophilic attack of $\mathrm{N}_{\mathrm{PS}}$ at the $\mathrm{C}_{\mathrm{A} 4}$ center. In contrast, however, this reaction proceeds via $\mathbf{T S}_{2 \mathrm{C}-2 \mathrm{D}}$ at a cost of only $1.2 \mathrm{kcal} / \mathrm{mol}$ with the resulting intermediate complex $2 \mathrm{D}^{\mathrm{PN}+}$ lying $5.4 \mathrm{kcal} / \mathrm{mol}$ lower in energy than $\mathbf{2 C}^{\mathbf{A K}+}\left(17.0 \mathrm{kcal} / \mathrm{mol}\right.$ higher in energy than $\left.\mathbf{1 A}^{\mathbf{A K}+}\right)$. Unlike that previously proposed for the Path 2 mechanism (Scheme 4), ${ }^{27,28} \mathrm{C}_{\mathrm{A} 4}-\mathrm{N}_{\mathrm{P} 5}$ bond formation does not occur with a concomitant proton transfer from the attacking $-\mathrm{NH}_{2}$ to the A-site imine $=\mathrm{NH}^{+}$group. Instead, this transfer occurs after $\mathrm{C}_{\mathrm{A} 4}-\mathrm{N}_{\mathrm{P} 5}$ bond formation and is found to be endergonic with the resulting intermediate $\mathbf{2} \mathbf{D}^{\mathbf{A K}+}$ lying $1.8 \mathrm{kcal} / \mathrm{mol}$ higher in energy. We were unable to definitively calculate the barrier for this proton transfer. However, just as for the related Path 1 conversion of $\mathbf{1 B}^{\mathbf{P N}+}$ to $1 \mathbf{B}^{\mathrm{AK}+}$ via proton transfer (see above), the barrier for this step is expected to be quite large as the TS also necessarily involves a four-membered ring structure. Similarly, however, as observed in Path 1, an active-site residue or $\mathrm{H}_{2} \mathrm{O}$ moiety may be able to participate in this step and lower the barrier. Structurally, it should be noted that the $\mathrm{C}_{\mathrm{A} 4}-\mathrm{N}_{\mathrm{P} 5}$ bond shortens considerably from 1.57 to $1.43 \AA$ upon going from $2 \mathbf{D}^{\mathbf{P N}+}$ to $2 \mathrm{D}^{\mathrm{AK}+}$, while the $\mathrm{C}_{\mathrm{A} 4}-\mathrm{N}_{\mathrm{AK}}$ bond concomitantly lengthens from 1.42 to $1.58 \AA$.

The next step is cleavage of the A-site enzyme-substrate bond via $\mathbf{T S}_{2 \mathbf{D}-2 \mathrm{E}}$. In the gas phase (i.e., without a polar envinroment), this reaction occurs with a barrier of $6.0 \mathrm{kcal} /$ mol. However, when free energy corrections and the effects of polarity of an aqueous environment are included, the reaction becomes barrierless. That is, upon formation, $\mathbf{2 D}^{\mathbf{A K}+}$ essentially immediately collapses to the A-site cleaved intermediate $\mathbf{2} \mathbf{E}^{\mathbf{P N}+}$ lying a further $6.8 \mathrm{kcal} / \mathrm{mol}$ lower in energy.

Complex $\mathbf{2} \mathbf{E}^{\mathbf{P N}+}$ is itself simply a higher energy conformer of $\mathbf{1} \mathbf{E}^{\mathbf{P N}+}$ on Path 1 (cf. Figure 3). Thus, once formed it can rearrange to either ${ }^{\mathbf{b}} \mathbf{1 E}^{\mathrm{PN}+}$ or ${ }^{\mathbf{f}} \mathbf{E}^{\mathbf{P N}+}$ and Path 2 then follows the same mechanism as already detailed above for Path 1 .

Path 3: Cleavage of the P-Site Enzyme-Substrate Bond Prior to Cyclization. The alternative mechanism Path 3 is shown in Scheme 5. It begins with the same reaction steps as proposed for Path 2 up to structure $\mathbf{2} \mathbf{C}^{\mathbf{A} \mathbf{K}}$. However, rather than then forming the second intersubstrate bond $\left(\mathrm{C}_{\mathrm{A} 4}-\mathrm{N}_{\mathrm{P} 5}\right)$, the P-site enzyme-substrate bond is instead cleaved first. The free energy PES obtained for this pathway is shown in Figure 3 while optimized structures of the intermediates and TS's unique to Path 3 are given in Figure 6.

Specifically, from structure $\mathbf{2} \mathrm{C}^{\mathrm{AK}+}$ the second $\mathrm{H}_{\mathrm{A} 3}$ proton is first transferred to the P-site $-\mathrm{NH}-$ moiety. This transfer can lead to either the $E$ - or a $Z$-symmetry intermediate $3 \mathrm{D}^{\mathrm{PK}+}$ :

${ }^{\mathrm{E}} 3 \mathrm{D}^{\mathrm{PK}+}$ and ${ }^{\mathbf{Z}} \mathrm{D}^{\mathrm{PK}+}$, respectively. However, within the limits of the current chemical model there are no bases available for the transfer of the proton. Consequently, this reaction must proceed via high-energy strained four-membered ring TS's (not shown). Furthermore, the formation of ${ }^{\mathbf{E}} \mathbf{3}{ }^{\mathrm{PK}+}$ and ${ }^{\mathbf{Z}} \mathbf{D D}^{\mathrm{PK}+}$ is relatively endergonic, by 10.9 and $17.0 \mathrm{kcal} / \mathrm{mol}$, respectively.

Next, the P-site enzyme-substrate bond is cleaved. That is,

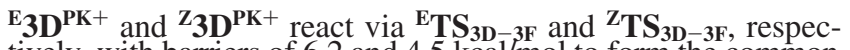
tively, with barriers of 6.2 and $4.5 \mathrm{kcal} / \mathrm{mol}$ to form the common cleaved intermediate $\mathbf{3} \mathbf{F}^{\mathbf{P N}+}$ (Figure 6). These barriers appear, by themselves, to be quite low. However, relative to the initial reactive complex $\mathbf{1} \mathbf{A}^{\mathbf{A K}+}$, they lie very high (at 39.5 and 43.9 $\mathrm{kcal} / \mathrm{mol}$ ) and are thus unlikely to be enzymatically feasible. This step is also remarkably exergonic by 27.4 and $33.4 \mathrm{kcal} /$ mol for $E$ - and $Z$-symmetry, respectively, in that $\mathbf{3 F ^ { \mathbf { P N } + }}$ lies just $6.0 \mathrm{kcal} / \mathrm{mol}$ higher in energy than the initial reactive complex $\mathbf{1 A}^{\mathrm{AK}+}$. It is noted that there is now a very strong interaction/ weak bond between $\mathrm{C}_{\mathrm{A} 4}$ and $\mathrm{N}_{\mathrm{P} 5}$. This is illustrated by the fact that the distance between them $(1.56 \AA)$ is only moderately longer than the $\mathrm{C}-\mathrm{N}$ bond in protonated methylamine, $1.52 \AA$, and that the $\mathrm{C}_{\mathrm{A} 4}$ center is slightly pyramidal (see Figure 6).

The subsequent step is an abstraction of a proton from the $-\mathrm{N}_{\mathrm{P} 5} \mathrm{H}_{2}{ }^{+}-$moiety by the amino group of the now free P-site lysyl residue. This occurs via ${ }^{1} \mathbf{T S}_{3 \mathrm{~F}-3 \mathrm{~F}}$ at the cost of $5.9 \mathrm{kcal} /$ mol to give $3 \mathbf{F}^{\mathbf{P K}+}$ lying higher in energy than $\mathbf{3 F}^{\mathbf{P N}+}$ by only $4.2 \mathrm{kcal} / \mathrm{mol}$ (Figure 3). This is followed by a very low barrier proton transfer $\left(0.2 \mathrm{kcal} / \mathrm{mol}\right.$ via $\left.{ }^{2} \mathbf{T S}_{3 \mathbf{F}-3 \mathrm{~F}}\right)$ from the now protonated A-site lysyl onto the substrate imine nitrogen $\left(\mathrm{N}_{\mathrm{AK}}\right.$, i.e., the Schiff-base nitrogen from the initial A-site lysyl residue). This overall "double proton transfer" process is slightly exergonic as the resulting complex $\mathbf{3} \mathbf{F}^{\mathbf{A K}+}$ lies $3.4 \mathrm{kcal} / \mathrm{mol}$ lower in energy than $3 \mathrm{~F}^{\mathbf{P N}+}$. Furthermore, the $\mathrm{C}_{\mathrm{A} 4}-\mathrm{N}_{\mathrm{P} 5}$ bond has now shortened significantly to $1.43 \AA$ and in fact is now slightly shorter than typical of a single $\mathrm{C}-\mathrm{N}$ bond (see above), while the $\mathrm{C}_{\mathrm{A} 4}-\mathrm{N}_{\mathrm{AK}}$ bond has lengthened to $1.56 \AA$. 

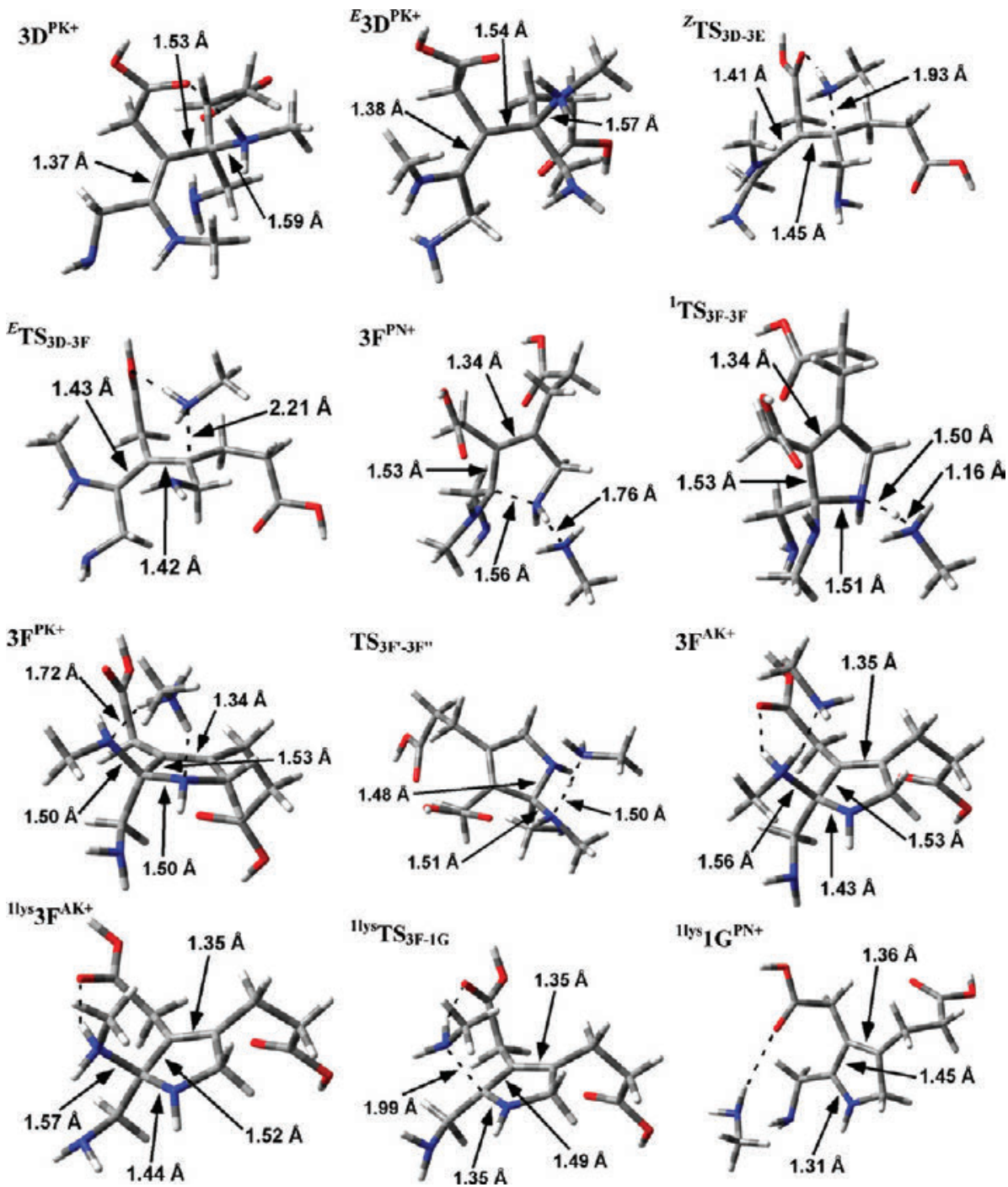

Figure 6. Optimized structures of intermediates and transition structures involved in Path 3.

For the same reasons outlined above for Path 1, we used a slightly reduced model $\left({ }^{1 \mathbf{l y s}} \mathbf{3} \mathbf{F}^{\mathbf{A K}+}\right.$ ) lacking the free P-site methylamine for the final step of Path 3, cleavage of the A-site enzyme-substrate bond (i.e., $\mathbf{3 F}^{\mathbf{A K}+} \rightarrow \mathbf{1 G}^{\mathbf{P N}+}$; Figure $3 \mathrm{~b}$, green line). Cleavage of the $\mathrm{C}-\mathrm{N}$ enzyme-substrate link proceeds via ${ }^{1 l y s} \mathbf{T S}_{\mathbf{3 F}-\mathbf{3 G}}$ at a cost of only $4.8 \mathrm{kcal} / \mathrm{mol}$ to give the final product complex ${ }^{{ }^{1 l y s}} \mathbf{1 G}^{\mathbf{P N}+}$ lying $9.2 \mathrm{kcal} / \mathrm{mol}$ lower in energy than the initial reactive complex $\mathbf{1 A}^{\mathbf{A K}+}$.

\section{Conclusions}

We have performed a systematic computational investigation, using DFT-based methods in combination with small yet appropriate chemical models, of the proposed catalytic mechanism of PBGS.

The transfer of the Schiff base from the A-site is at this level of theory found to be a possible way for Schiff-base formation at the P-site. The protonated system has a lower rate-determining step $(7.4 \mathrm{kcal} / \mathrm{mol})$ than the neutral system. However, in the environment of the whole active site this process could take another turn since the carboxylic acid is probably hydrogen bonded to other residues, and the role of the zinc ion is not taken into account.

It can be seen that in each of the above three mechanisms considered for the pyrrole ring formation, the first of the two intersubstrate bonds formed has the highest activation energy.
That is, the barrier for a particular reaction step depends on its position in the overall mechanism. For instance, in Path 2, formation of the $\mathrm{C}_{\mathrm{A} 3}-\mathrm{C}_{\mathrm{P} 4}$ intersubstrate bond has a higher barrier than in Path 1, where this step occurs later in the mechanism. The barrier of the $\mathrm{C}_{\mathrm{A} 4}-\mathrm{N}_{\mathrm{P} 5}$ intersubstrate bond formation is very low in Paths 2 and 3 , when the $\mathrm{C}_{\mathrm{A} 3}-\mathrm{C}_{\mathrm{P} 4}$ bond is already formed, but higher in Path 1, when this is the first step in the reaction.

The highest barrier in Path 1 is the formation of the $\mathrm{C}_{\mathrm{A} 3}-\mathrm{C}_{\mathrm{P} 4}$ intersubstrate bond $\left(\mathbf{T S}_{\mathbf{1} \times \mathbf{1 0}^{-1} \mathbf{F}}\right.$ for both the front and back process), with a barrier of $21.4 \mathrm{kcal} / \mathrm{mol}$ relative to the reactive complex $\left(\mathbf{1 A}^{\mathrm{AK}+}\right)$.

For Path 2 the same process (formation of the $\mathrm{C}_{\mathrm{A} 3}-\mathrm{C}_{\mathrm{P} 4}$ intersubstrate bond) represents the rate-limiting step $\left(\mathbf{T S}_{\mathbf{2 B}-\mathbf{2}} \mathbf{C}\right)$. However, due to the order in which this bond is formed, it was found to have barrier of $32.1 \mathrm{kcal} / \mathrm{mol}$ relative to the reactive complex $\left(\mathbf{1 A}^{\mathbf{A K}+}\right)$. In addition, the intermediate structures were found to lie much higher in energy than Path 1, since these first two steps along Path 2 are very endergonic (cf. Figure 3).

Path 3 follows the same route as Path 2 in the first step and shares the same rate-determining step. The (3C-3D) transition state was not calculated but is thermochemically a very endergonic step. The largest energy difference to the initial structure $\mathbf{1} \mathbf{A}^{\mathbf{A K}+}$ is seen for $Z-\mathbf{3 D}^{\mathbf{P K}+}$ with $39.4 \mathrm{kcal} / \mathrm{mol}$, which is unfavored over the formation of the corresponding $E$-isomer. 
The last steps, however, have quite low barriers, and the steps are exergonic.

The energy barriers found are in good agreement with experimental data, where the activation energy of PBGS was found to be $18.4 \mathrm{kcal} / \mathrm{mol}^{42}$ The results suggest that Path 1 with initial $\mathrm{C}-\mathrm{N}$ bond formation is the thermodynamically most viable route, given the lower endergonicity displayed in several of the intermediate steps. However, also other factors such as explicit influence of the active site cavity (not included herein) may influence the barriers and provide a more definite discrimination between the feasibility of the two pathways.

Acknowledgment. The Swedish Chemical Society (E.E.), the Swedish Research Council, the Faculty of Science and Technology at Örebro University, and the National University of Ireland, Galway (L.A.E.), and NSERC (J.W.G.) are gratefully acknowledged for funding. SHARCNET is acknowledged for additional computational resources.

Supporting Information Available: Cartesian coordinate and relative free energies for water-assisted process $1 \mathrm{~B}^{\mathrm{PN}+} \rightarrow$ $\mathrm{TS}_{1 \mathrm{~B}-1 \mathrm{~B}} \rightarrow 1 \mathrm{~B}^{\mathrm{AK}+}$. This material is available free of charge via the Internet at http://pubs.acs.org.

\section{References and Notes}

(1) Neier, R. Advances in Nitrogen Heterocycles; JAI Press: London, 1996; Vol. 2

(2) Heinemann, I. U.; Jahn, M.; Jahn, D. Arch. Biochem. Biophys. 2008 $474,238$.

(3) Jaffe, E. K. J. Bioenerg. Biomembr. 1995, 27, 169.

(4) Warren, M. J.; Cooper, J. B ; Wood, S. P.; Shoolingin-Jordan, P. M. Trends Biochem. Sci. 1998, 23, 217.

(5) Erskine, P. T.; Newbold, R.; Brindley, A. A.; Wood, S. P Shoolingin-Jordan, P. M.; Warren, M. J.; Cooper, J. B. J. Mol. Biol. 2001, 312,133 .

(6) Shoolingin-Jordan, P. M.; Spencer, P.; Sarwar, M.; Erskine, P. E.; Cheung, K. M.; Cooper, J. B.; Norton, E. B. Biochem. Soc. Trans. 2002, 30,584 .

(7) Erskine, P. T ; Senior, N.; Awan, S.; Lambert, R.; Lewis, G ; Tickle, L. J.; Sarwar, M.; Spencer, P.; Thomas, P.; Warren, M. J.; ShoolinginJordan, P. M.; Wood, S. P.; Cooper, J. B. Nat. Struct. Biol. 1997, 4, 1025.

(8) Erskine, P. T.; Coates, L.; Newbold, R.; Brindley, A. A.; Stauffer, F.; Wood, S. P.; Warren, M. J.; Cooper, J. B.; Shoolingin-Jordan, P. M.; Neier, R. FEBS Lett. 2001, 503, 196

(9) Erskine, P. T.; Coates, L.; Butler, D ; Youell, J. H ; Brindley, A. A.; Wood, S. P.; Warren, M. J.; Shoolingin-Jordan, P. M.; Cooper, J. B. Biochem. J. 2003, 373, 733.

(10) Frere, F.; Schubert, W. D.; Stauffer, F.; Frankenberg, N.; Neier, R.; Jahn, D.; Heinz, D. W. J. Mol. Biol. 2002, 320, 237.

(11) Jaffe, E. K. Chem. Biol. 2003, 10, 25.

(12) Jordan, P. M. Biosynthesis of Tetrapyrroles; Elsevier: Amsterdam, 1991; Vol. 19.

(13) Jaffe, E. K.; Martins, J.; Li, J.; Kervinen, J ; Dunbrack, R. L. J. Biol. Chem. 2001, 276, 1531.
(14) Jarret, C.; Stauffer, F.; Henz, M. E.; Marty, M.; Luond, R. M.; Bobalova, J.; Schurmann, P.; Neier, R. Chem. Biol. 2000, 7, 185.

(15) Jaffe, E. K.; Hanes, D. J. Biol. Chem. 1986, 261, 9348.

(16) Jaffe, E. K.; Markham, G. D.; Rajagopalan, J. S. Biochemistry 1990, 29,8345 .

(17) Mills-Davies, N. L.; Thompson, D.; Cooper, J. B.; Wood, S. P.; Shoolingin-Jordan, P. M. 2001.

(18) Jaffe, E. K. Bioorg. Chem. 2004, 32, 316.

(19) Kervinen, J.; Jaffe, E. K.; Stauffer, F.; Neier, R.; Wlodawer, A.; Zdanov, A. Biochemistry 2001, 40, 8227.

(20) Nandi, D. L.; Shemin, D. J. Biol. Chem. 1968, 243, 1236.

(21) Gibbs, P. N. B.; Jordan, P. M. Biochem. J. 1986, 236, 447.

(22) Jordan, P. M.; Gibbs, P. N. B. Biochem. J. 1985, 227, 1015.

(23) Jordan, P. M.; Seehra, J. S. FEBS Lett. 1980, 114, 283.

(24) Jordan, P. M.; Seehra, J. S. J. Chem. Soc., Chem. Commun. 1980, 240.

(25) Breinig, S.; Kervinen, J.; Stith, L.; Wasson, A. S.; Fairman, R.; Wlodawer, A.; Zdanov, A.; Jaffe, E. K. Nat. Struct. Biol. 2003, 10, 757.

(26) Granick, S.; Mauzerall, D. J. Biol. Chem. 1958, 232, 1119.

(27) Goodwin, C. E.; Leeper, F. J. Org. Biomol. Chem. 2003, 1, 1443.

(28) Frere, F.; Nentwich, M.; Gacond, S.; Heinz, D. W.; Neier, R.; Frankenberg-Dinkel, N. Biochemistry 2006, 45, 8243.

(29) Baldwin, J. E. J. Chem. Soc., Chem. Commun. 1976, 734

(30) Erdtman, E.; Bushnell, E. A. C.; Gauld, J. W.; Eriksson, L. A. J. Mol. Struct. (THEOCHEM) Submitted for publication, 2010

(31) Appleton, D.; Leeper, F. J. Bioorg. Med. Chem. Lett. 1996, 6, 1191.

(32) Abboud, M. M.; Akhtar, M. J. Chem. Soc., Chem. Commun. 1976, 1007.

(33) Chaudhry, A. G.; Jordan, P. M. Biochem. Soc. Trans. 1976, 4, 760.

(34) Frisch, M. J.; Trucks, G. W.; Schlegel, H. B.; Scuseria, G. E.; Robb, M. A.; Cheeseman, J. R., Jr.; Vreven, T.; Kudin, K. N.; Burant, J. C.; Millam, J. M.; Iyengar, S. S.; Tomasi, J.; Barone, V.; Mennucci, B.; Cossi, M.; Scalmani, G.; Rega, N.; Petersson, G. A.; Nakatsuji, H.; Hada, M.; Ehara, M.; Toyota, K.; Fukuda, R.; Hasegawa, J.; Ishida, M.; Nakajima, T.; Honda, Y.; Kitao, O.; Nakai, H.; Klene, M.; Li, X.; Knox, J. E.; Hratchian, H. P.; Cross, J. B.; Bakken, V.; Adamo, C.; Jaramillo, J.; Gomperts, R.; Stratmann, R. E.; Yazyev, O.; Austin, A. J.; Cammi, R.; Pomelli, C.; Ochterski, J. W.; Ayala, P. Y.; Morokuma, K.; Voth, G. A.; Salvador, P.; Dannenberg, J. J.; Zakrzewski, V. G.; Dapprich, S.; Daniels, A. D.; Strain, M. C.; Farkas, O.; Malick, D. K.; Rabuck, A. D.; Raghavachari, K.; Foresman, J. B.; Ortiz, J. V.; Cui, Q.; Baboul, A. G.; Clifford, S.; Cioslowski, J.; Stefanov, B. B.; Liu, G.; Liashenko, A.; Piskorz, P.; Komaromi, I.; Martin, R. L.; Fox, D. J.; Keith, T.; Al-Laham, M. A.; Peng, C. Y.; Nanayakkara, A.; Challacombe, M.; Gill, P. M. W.; Johnson, B.; Chen, W.; Wong, M. W.; Gonzalez, C.; Pople, J. A. Gaussian 03, Revision D.02; Gaussian Inc.: Wallingford, CT, 2004.

(35) Becke, A. D. J. Chem. Phys. 1993, 98, 1372.

(36) Becke, A. D. J. Chem. Phys. 1993, 98, 5648.

(37) Lee, C. T.; Yang, W. T.; Parr, R. G. Phys. Rev. B 1988, 37, 785.

(38) Stephens, P. J.; Devlin, F. J.; Chabalowski, C. F.; Frisch, M. J. J. Phys. Chem. 1994, 98, 11623.

(39) Vosko, S. H.; Wilk, L.; Nusair, M. Can. J. Phys. 1980, 58, 1200.

(40) Llano, J., Gauld, J. W. Mechanistics of Enzyme Catalysis: From Small to Large Active-Site Models; Wiley-VCH: Weinheim, Germany, 2010; Vol. 2.

(41) Siegbahn, P. E. M.; Borowski, T. Acc. Chem. Res. 2006, 39, 729.

(42) Schlosser, M.; Beyersmann, D. Biol. Chem. Hoppe-Seyler 1987, 368,1469 . 